\title{
Asymmetric Induction in C-Alkylation of Tropane-Derived Enamines: Congruence Between Computation and Experiment
}

Yifei Li, Kelvin E. Jackson, Andrew Charlton, Ben Le Neve-Foster, Asma Khurshid, Heinrich-K. A. Rudy,

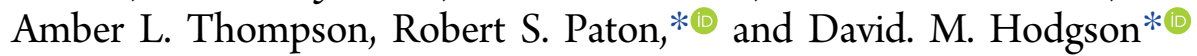

Department of Chemistry, Chemistry Research Laboratory, University of Oxford, Mansfield Road, Oxford OX1 3TA, U.K.

\section{Supporting Information}

ABSTRACT: Quantum chemical studies of C-ethylation of 1methyl- and 1,4,4-trimethyl-tropane-derived enamines predict good (89:11 er, B3LYP) and high (98:2 er, B3LYP) levels, respectively, of asymmetric induction in the resulting $\alpha$ alkylated aldehydes. The nonracemic tropanes were synthe-

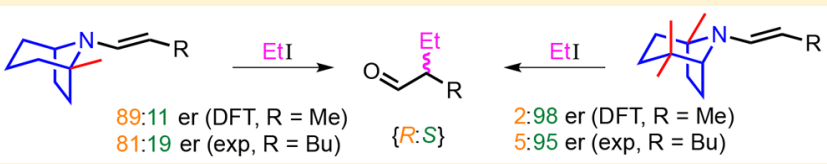
sized using Mannich cyclization strategies (Robinson-Schöpf and by way of a Davis-type $N$-sulfinyl amino bisketal, respectively), and ethylation of the derived enamines was found to support the predicted sense and magnitude of asymmetric induction (81:19 er and 95:5 er, respectively). A comparison of several computational methods highlights the robustness of predicted trends in enantioselectivity, enabling theory to guide synthesis.

\section{INTRODUCTION}

Chiral $\alpha$-alkyl-substituted aldehydes are important building blocks for organic synthesis. Several methods to make them involve a chiral auxiliary alkylation strategy and have proven effective for asymmetric induction, but each approach is not without specific drawbacks. ${ }^{1}$ The primary method for generation of enantioenriched $\alpha$-alkyl-substituted aldehydes through alkylation by nucleophilic substitution with $\mathrm{S}_{\mathrm{N}} 2$ reactive electrophiles involves the use of Enders' lithiated SAMP/RAMP hydrazones, although the requirement for low temperature (usually -80 to $-120{ }^{\circ} \mathrm{C}$ ) and the need for subsequent ozonolysis in cleavage of the auxiliary can cause problems. ${ }^{2,3}$ Alkylations are well-known with Evans' oxazolidinone $^{4}$ or Myers' pseudoephedrine ${ }^{5}$ auxiliaries, but once again further manipulation to the aldehyde is required by the removal of these auxiliaries through reduction. ${ }^{6}$ Catalytic $\alpha$-alkylation of aldehydes by way of transient enamines has attracted much attention in recent years, ${ }^{1}$ with the process being described as the "Holy Grail" of organocatalysis. ${ }^{7}$ This task with $S_{N} 2$ reactive electrophiles has proven to be challenging, particularly due to undesired side-reactions such as self-aldolization of the aldehydes, and $\mathrm{N}$ - or $\mathrm{O}$-alkylation of the catalysts. Work by MacMillan on asymmetric one-electron-mediated organic transformations using photoredox-organocatalysis constitutes an elegant strategy for performing such catalysis, however this method with organohalides requires a radical capto-stabilizing group on the alkylating partner, reducing the scope of this technique. $^{8,9}$

While organocatalytic $\alpha$-alkyl-substituted aldehyde generation through intermolecular nucleophilic substitution remains problematic, $1,7,10$ we have been investigating alkylation of preformed chiral aldenamines as an expedient route to $\alpha$ alkylated aldehydes. Steric shielding around $\mathrm{N}$ is required in such systems to provide bias for $C$-alkylation. Our early studies with $\alpha, \alpha, \alpha^{\prime}$-trialkylsubstituted piperidine-based auxiliaries pro- vided a promising start (88:12 to $94: 6$ er for ethylation). ${ }^{11}$ Issues with conformational flexibility and inactive ground state conformers (lacking $N$ lone pair $-\pi^{*}$ overlap) led us to then examine rigidified systems: tropane-derived enamine $\mathbf{1}$ and homotropane-derived enamine $\mathbf{2}$ (Scheme 1$).{ }^{12}$ On ethylation,

Scheme 1. Asymmetric Alkylation of Tropane and Homotropane-Derived Enamines 1 and $2^{12}$

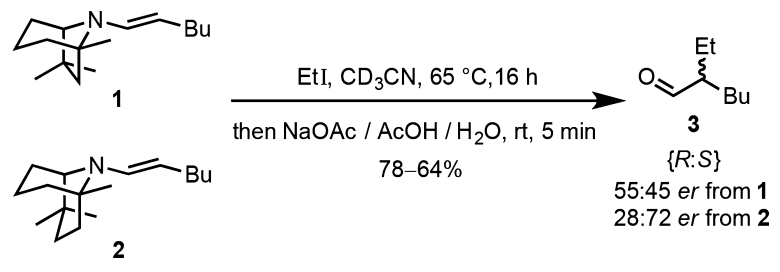

these latter systems gave 2-ethylhexanal (3) in 45:55 and 72:28 ers, respectively, with the low er from tropane 1 being accompanied by an initially unexpected reversal in the sense of asymmetric induction. These observations were rationalized through computational investigations of the competing alkylation transition structures (TSs). ${ }^{12}$ The (slight) bias for ethylation of tropane-derived enamine 1 from the 5- rather than the 6-membered side of the bicycle, even though the 5membered side possesses ostensibly the greatest steric hindrance, was particularly intriguing. In contrast to this earlier study, where DFT calculations were used to rationalize empirical results, the present work describes the use of computation as a predictive tool. The computational prediction and design of catalysts and reactions is still far from routine, ${ }^{13}$ and few examples of stereoselective catalysts or reactions synthesized according to computational designs have been

Received: August 3, 2017

Published: September 27, 2017 
reported. ${ }^{14,15}$ In the current study, we show computed trends in enantioselectivity that are relatively robust across different theoretical methods, allowing confident, qualitative, predictions to be made. Initial investigation of the intrinsic bias of tropanederived enamine alkylation proved the model's accuracy experimentally. These results were then used to inform the design of a new tropane auxiliary with sufficient hindrance on the 6-membered side to induce a significantly improved level of asymmetric alkylation.

\section{RESULTS AND DISCUSSION}

The stereoselective ethylation of enamines $\mathbf{1}$ and $\mathbf{2}$ was modeled by us previously with the B3LYP density functional. ${ }^{12}$ A large body of work (most notably from Houk) using this level of theory has successfully rationalized the stereochemical outcome of enamine reactions. ${ }^{16}$ Despite the shortcomings of the B3LYP functional, it remains a cost-effective method for geometry optimization in the face of multiple conformations and organic reaction pathways. ${ }^{17}$ In our case, TS conformers were systematically optimized and the levels of stereoselectivity computed from the B3LYP Boltzmann populations. Qualitatively, the reversal in facial selectivity between $\mathbf{1}$ and $\mathbf{2}$ was reproduced, and the quantitative magnitudes of stereoselectivity were also described reasonably well. The use of quasi-rigid rotor harmonic oscillator ( $\mathrm{qRRHO}$ ) corrected Gibbs energies lessens the influence of erroneously large vibrational entropies associated with low frequency normal modes on the computed selectivities. ${ }^{18}$ As in our earlier studies, ${ }^{11,12}$ the $n$-butyl group of the experimentally examined enamines was truncated to a methyl group for computational work. The 27 -fold reduction in conformational space makes the computational study feasible, while retaining the important steric effects.

Computations for the bicyclic amine-derived enamines showed that the presence of the bridgehead methyl group leads, due to minimization of allylic strain, to only one relevant rotamer about the exocyclic $\mathrm{C}-\mathrm{N}$ bond (the anti form, referring to the relationship between the double bond and the $\mathrm{N}-\mathrm{C}$ bond bearing the bridgehead methyl). ${ }^{11 \mathrm{~d}}$ Furthermore, the calculations indicated that tropane-derived enamine $1 *$ preferentially adopts a conformation in which the fivemembered ring is oriented further away from the enamine than the six-membered ring. As a result, the exo-methyl of the gem-dimethyl group is unable to exert a steric influence in the alkylation transition states, and the modest preference for alkylation on the side of the five-membered ring is directed by an axial exo-hydrogen of the six-membered ring (Figure 1). There is no such conformational bias in homotropane-derived enamine $2 *$, where the exo-methyl lies closer to the site of reactivity and modestly influences alkylation to occur on the side of the unsubstituted six-membered ring. Observing that a difference in ring size influences enamine conformation led us to hypothesize that enamine $4^{*}$, lacking the biasing element of the gem-dimethyl group, should also undergo stereoselective alkylation (compared with enamine $1^{*}$, the lack of an endomethyl group in enamine $4^{*}$ does not result in axial exo-H being any less close to the $=\mathrm{C}$ that undergoes alkylation: the $\mathrm{H} \cdots \mathrm{C}$ distances being $2.85 \AA$ in $1^{*}$ and $2.86 \AA$ in $4 *$ ). The level of asymmetric induction with this system would be intriguing as, aside from the bridgehead methyl necessary to confer chirality and restrict the enamine to one rotamer, facial bias on alkylation would simply be dependent on the influence of different ring sizes (5 versus 6 ) in the otherwise unsubstituted $\mathrm{N}$-bridged bicyclic system $4 *$. The global minimum energy
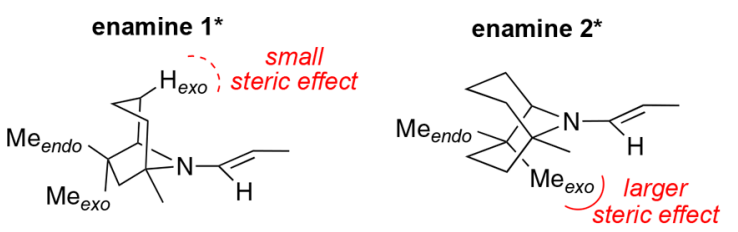

enamine conformation: $\mathrm{Me}_{\text {exo }}$ oriented away from the electrophile

$\mathrm{Me}_{\text {exo }}$ oriented closer to the electrophile
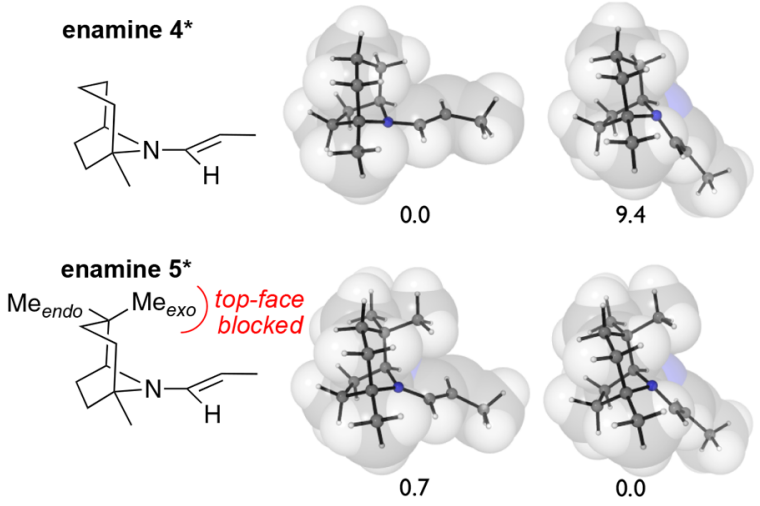

Figure 1. Enamine conformations with B3LYP/6-31G(d) relative energies in $\mathrm{kJ} / \mathrm{mol}$.

conformation of this enamine illustrates this design element, the $\mathrm{N}$ atom being pyramidalized and the $\mathrm{C}=\mathrm{C}$ bond siting closer to the six-membered ring. Moreover, models of enamine $5 *$ showed that the incorporation of the gem-dimethyl group in the six-membered ring should, in combination with the conformational bias already described, effectively shield approach to the enamine from the side of the six-membered ring (modeling was performed for the same enantiomeric series as $4 *$, although in subsequent experimental work the "opposite" enantiomer was synthesized). The introduction of this additional biasing element results in two ground state conformations of similar stability. We turned to computations of the competing TSs to predict the sense and levels of stereoinduction resulting from the proposed structural changes.

Alkylation of $4 *$ was predicted to occur preferentially on the same side as the five-membered ring (Figure 2). This reflects the ground-state conformational bias of the enamine (Figure

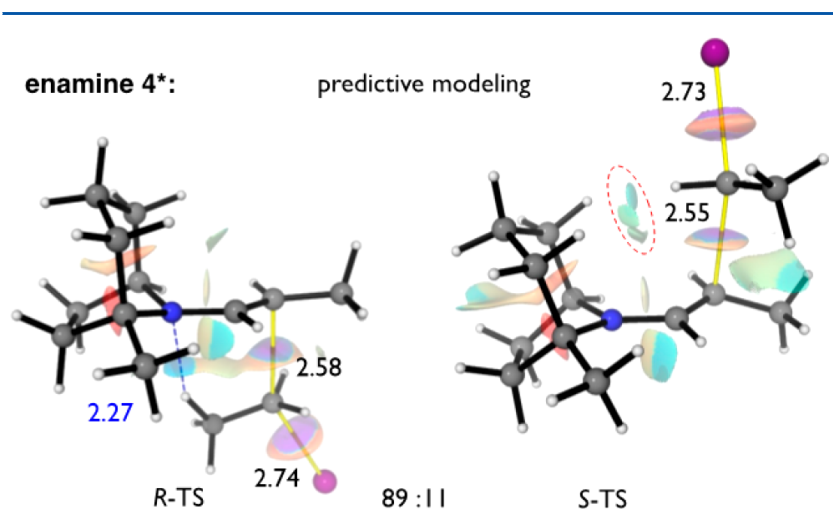

Figure 2. Predicted stereoselectivity for ethylation of enamine $4 *$. Most stable (R)- and (S)- B3LYP/6-31G(d)+LANL2DZ transition structures, with forming/breaking distances $(\AA)$. NCI isosurfaces highlight noncovalent interactions (blue $=$ attractive; green $=$ weakly interacting; red $=$ repulsive). The proximity of an $\mathrm{H}_{\text {exo }}$ atom with the electrophile in the less favorable $(S)$-TS gives rise to nonbonding interactions in the less favored TS. 
Scheme 2. Synthesis and Alkylation of 1-Methyltropane-Derived Enamine (1S,5R)-4

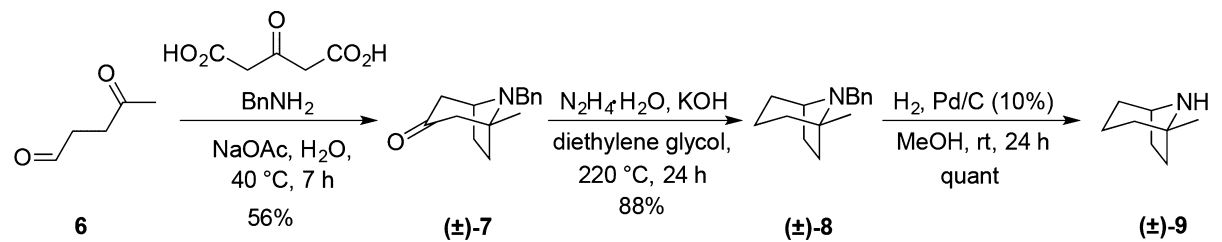
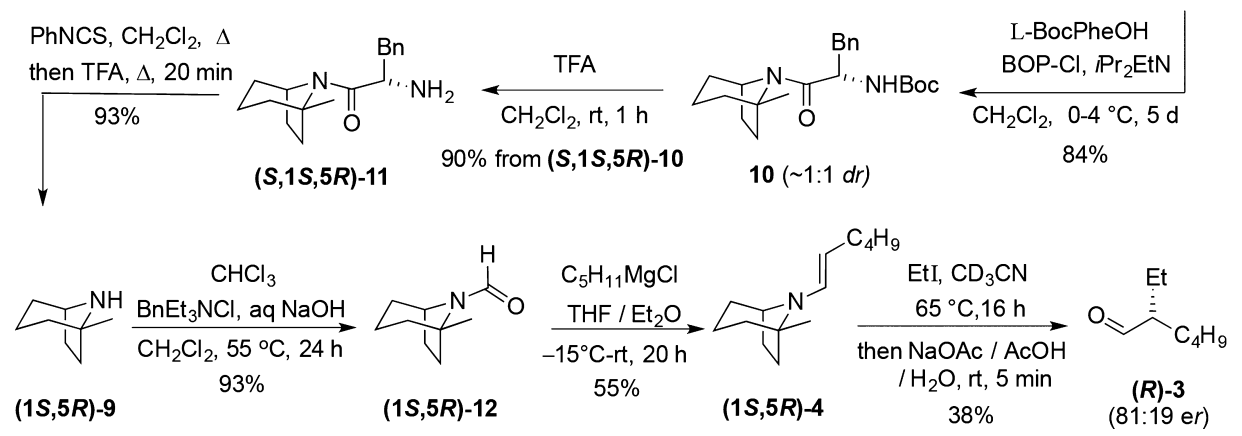

1). Nonbonding contacts between the axial $\mathrm{H}$ atoms and the electrophile are visible in the noncovalent interaction (NCI) isosurface of the disfavored pathway (Figure 2). We also noticed a favorable $\mathrm{N}$---HC interaction in the most favored TS, which requires orientation of the electrophile Me group toward nitrogen. Such a conformation is sterically more challenging for the other enamine face (see Figure S2). The sense of stereoinduction was predicted to be the same as computed and observed for enamine 1, but showing higher levels of selectivity. The selectivity predictions were obtained from the Boltzmann population over six conformations; a further six TSs were also evaluated for alkylation of the minor (syn) rotamer, however, these did not contribute appreciably to the observed selectivity.

So as to examine experimentally the above predicted asymmetric induction for enamine $4 *$, synthesis of the chiral tropane $\mathbf{4}$ was accomplished (Scheme 2 ) by following a strategy similar to that used to access tropane-derived enamine $\mathbf{1}$, involving a Robinson-Schöpf reaction and resolution. ${ }^{12}$ As such, 4-oxopentanal $(6)^{19}$ was first converted to racemic 2methylnortropane $(( \pm)-9)$ in three steps: Robinson-Schöpf reaction ${ }^{20}$ to give $N$-benzyl tropinone $( \pm)-7$, followed by Wolff-Kishner reduction to $N$-benzyltropane $( \pm)-8$ and then debenzylation by hydrogenolysis. ${ }^{21}$

Resolution of 2-methylnortropane $(( \pm)-9)$ was achieved through coupling with $N$-Boc-L-phenylalanine and chromatographic separation of the resulting diastereomeric Bocprotected $\alpha$-amino amides $10 .{ }^{12}$ Boc-protected $\alpha$-amino amide $(S, \mathbf{1 S}, \mathbf{5 R})$-10 was carried forward to $(+)$-2-methylnortropane $((1 S, 5 R)-9)$ by TFA-induced Boc deprotection to give $\alpha$-amino amide $(\mathbf{1 S}, \mathbf{5 R})-11$, followed by Edman degradation (Scheme 2). ${ }^{22}$ The absolute configuration of 2-methylnortropane $((+)-9)$ was assigned by single crystal X-ray diffraction studies of the TFA salt from deprotection of Boc-protected $\alpha$ amino amide $(S, \mathbf{1} R, \mathbf{5 S})-10 .^{23}$ With 2-methylnortropane $((+)-9)$ in hand, conversion to a representative enamine (1S,5R)-4 was examined (choosing the $n$-butyl-substituted analogue for consistency with our previous studies). The absence of further substitution in either ring of 2-methylnortropane suggested that application of enamine-forming condensation conditions $\left(\mathrm{K}_{2} \mathrm{CO}_{3}, \mathrm{Et}_{2} \mathrm{O}, \mathrm{rt}, 16 \mathrm{~h}\right)$ for modestly hindered secondary amines and aliphatic aldehydes might be viable ${ }^{11 c, 24}$ however, when attempted, condensation conditions only returned unreacted 2-methylnortropane together with the $\alpha, \beta$-unsaturated aldehyde from self-aldol condensation of hexanal. ${ }^{25}$ In contrast, the two-step procedure used successfully to access enamines $\mathbf{1}$ and $\mathbf{2}^{12}$ gave the desired, hydrolytically unstable, E-enamine $(\mathbf{1} S, \mathbf{5 R})-\mathbf{4}$. This chemistry involves Grignard addition to the derived formamide (1S,5R)-12 (0.5 g, 92:8 er by HPLC analysis) under Hansson and Wickberg's nonaqueous workup modification ${ }^{26}$ of the classical Bouveault aldehyde synthesis. Pleasingly, enamine (1S,5R)-4 underwent alkylation with EtI to give aldehyde (R)-3 in similar er (81:19) to that predicted earlier by computational analysis (89:11 with B3LYP). The modest yield in this reaction (38\%), compared with alkylation of tropane $\mathbf{1}(78 \%$, Scheme 1$)$, may in part at least stem from significant competing $N$-alkylation. While the quaternary ammonium salt $\mathbf{S 2} \mathbf{- 3}$ was not isolated, its presence (1.6:1, C-: $N$ - ethylation) was tentatively assigned on the basis of direct ${ }^{1} \mathrm{H}$ NMR analysis of the reaction ${ }^{23}$ (following heating at $65{ }^{\circ} \mathrm{C}$ for $16 \mathrm{~h}$ ) before hydrolysis; prolonged heating, for a further $48 \mathrm{~h}$, did not alter the ratio of $C$-:N-ethylation. Computational analysis indicated that, for this comparatively less-hindered enamine, $N$-ethylation would also be kinetically favored on the side of the 5-membered ring (by $\sim 13 \mathrm{~kJ} / \mathrm{mol}$, Figure S3).

Calculated levels of selectivity for $5^{*}$ were noticeably higher (B3LYP predicted 98:2, Figure 3) than for any of those enamines studied previously. The most stable TS conformer was the same as for $4^{*}$, with the electrophile $\mathrm{CH}$ interacting with the enamine $\mathrm{N}$ atom. Nonbonding interactions between the axial methyl group and electrophile are visible from the $\mathrm{NCI}$ isosurface, giving greater levels of stereoinduction than $4^{*}$.

The above computational studies indicated that significant asymmetric induction would be provided by methyl substitution in the 6-membered ring at the 4-position. To study this experimentally, 1,4,4-trimethylnortropane $(1 R, 5 R)-20$ was synthesized (Scheme 3) following a strategy related to that used to construct homonortropane-derived enamine $2^{12}$ involving Mannich cyclization chemistry developed by Davis. $^{27}$ The Mannich cyclization substrate was prepared by addition of organolithium $14^{28}$ to sulfinimine $(R)-13$ (prepared in five steps from ethyl $\alpha$-methylacetoacetate), ${ }^{12}$ which gave bisketal sulfinamide $\left(\boldsymbol{R}_{S}, \boldsymbol{R}\right)-\mathbf{1 5}$ in excellent yield (89\%, 90:10 
enamine $5^{\star}$ : $\quad$ predictive modeling
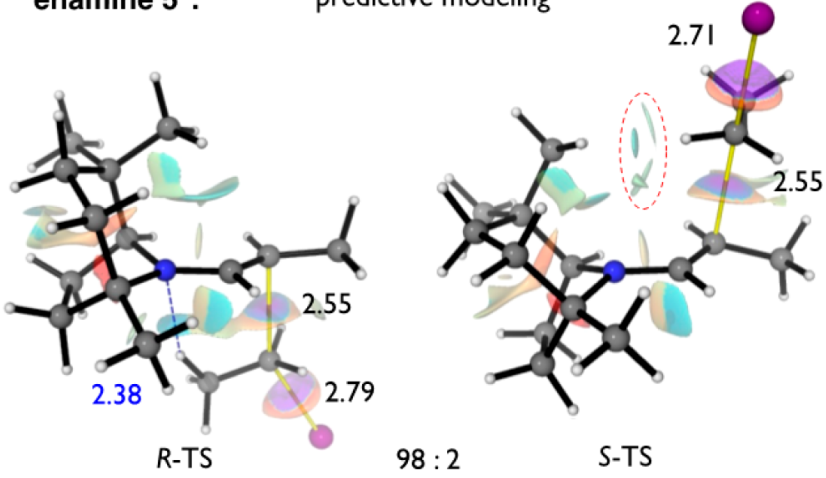

Figure 3. Predicted stereoselectivity for ethylation of enamine $5^{*}$. Most stable $(R)$ - and $(S)$ - B3LYP/6-31G(d)+LANL2DZ TSs shown, with forming/breaking distances $(\AA)$. NCI isosurfaces highlight the proximity of the $\mathrm{Me}_{\text {exo }}$ group with the electrophile in the less favorable (S)-TS.

$d r)$; the configuration of the dominant diastereomer was assigned by analogy to our earlier work ${ }^{12}$ and the sense of asymmetric induction observed on alkylation of enamine $(\mathbf{1}, \mathbf{5 R})-\mathbf{5}$ (vide infra). Heating bisketal sulfinamide $\left(\boldsymbol{R}_{S}, \boldsymbol{R}\right)$ 15 in an ethanolic-ethereal solution of $\mathrm{HCl}$ gave the desired trimethylnortropinone (1S,5R)-16 (67\%, 51\% following recrystallization), which was deoxygenated to 1,4,4-trimethylnortropane $(1 R, 5 R)-20$ by a four-step sequence comprising reduction to the nortropinol $(\mathbf{1 S , 5 R})-17(57: 43 d r)$, deoxygenation of the derived xanthate (1S,5R)-18 under BartonMcCombie conditions and hydrolysis of the resulting dithiocarbamate $(1 R, 5 R)-19$. Ethylation of enamine $(1 R, 5 R)$ 5 prepared (similarly to enamine $(1 S, 5 R)-4)$ by way of the enantiopure (by HPLC analysis) ${ }^{23}$ formamide (1R,5R)-21 (0.4 g), proceeded in reasonable yield (63\%) and high er (95:5, Scheme 3); once again providing a close match with the predetermined computational value (i.e., 98:2 with B3LYP). In this case, no evidence of competing $N$-ethylation was observed by direct ${ }^{1} \mathrm{H}$ NMR analysis of the reaction ${ }^{23}$ (following heating at $65{ }^{\circ} \mathrm{C}$ for $16 \mathrm{~h}$ ) before hydrolysis.

Throughout this work the B3LYP functional performed well in describing, and importantly predicting, levels of enantioselectivity and trends between the four synthesized enamines. Relatively small energetic differences between competing TSs can be influenced by noncovalent interactions, notably dispersion forces, and the performance of B3LYP, which lacks long-range correlation effects (as do all semilocal functionals), is perhaps surprisingly good. In this respect, intermolecular basis-set superposition error can mimic the effects of dispersion, albeit in an unphysical way, and equally, dispersion corrections in combination with small basis sets should be approached carefully. $^{29}$ We repeated our computational analysis with different density functionals, optimizing all competing TSs for each enamine with the implicit (M06-2X) and explicit (B3LYPD3, wB97XD) inclusion of dispersion effects (Figure 4). ${ }^{30}$

The increase in enantioselectivity progressing from enamines $1,2,4$, and 5 obtained experimentally is captured by all four functionals tested (using $1^{*}, 2^{*}, 4^{*}$, and $5^{*}$ ). Dispersion is evidently not a decisive element of stereocontrol for these reactions. The experimentally and computationally observed differences in facial selectivity between enamines $1(*)$ and $4(*)$ indicate that the presence of the 6-exo Me in $1(*)$ does slightly work against the inherent bias for alkylation on the side of the five-membered ring. These computational studies suggest a contributory factor to this: the favored transition state for $4^{*}$ with a favorable $\mathrm{N}-\mathrm{H}$ interaction is not seen analogously for $1^{*}$, as this would result in nonbonded steric interactions between the 6-exo Me and the electrophile. While B3LYP-D3, M06-2X, and wB97XD gave quantitative values of enantioselectivity closer to experiment for 2, B3LYP predictions were actually closer to the final experimental selectivities of $\mathbf{4}$ and $\mathbf{5}$. For each diastereomeric pair of TSs, differences in forming and breaking bond distances vary only slightly across different levels of theory (ca. 0.01-0.03 $\AA$ ). Energy differences between major and minor pathways are therefore relatively insensitive, leading

Scheme 3. Synthesis and Alkylation of 1,4,4-Trimethyltropane-Derived Enamine (1R,5R)-5

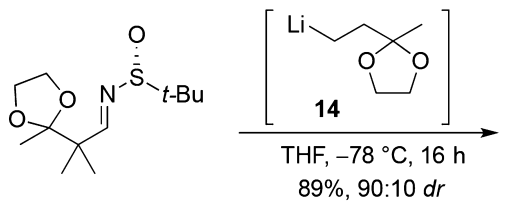

$(R)-13$<smiles>CC1(CC[C@H](NB(O)C(C)(C)C)C(C)(C)C)OCCO1</smiles>

$\left(R_{\mathrm{S}}, R\right)-15$

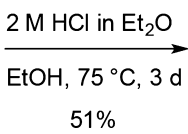

$51 \%$

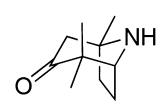

$(1 S, 5 R)-16$

$$
\text { THF, } 00^{\circ} \mathrm{C}-\mathrm{rt}, 16 \mathrm{~h} \mid 97 \%
$$

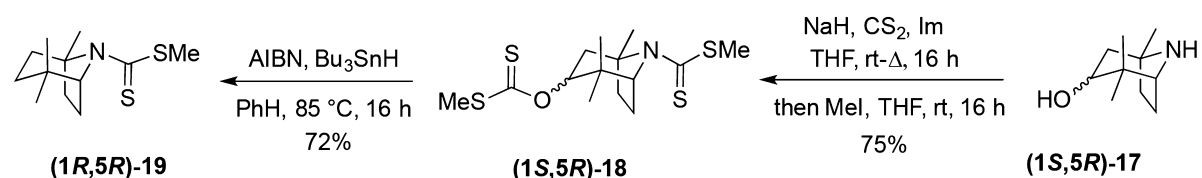

$\downarrow \begin{aligned} & 6 \mathrm{M} \mathrm{HCl}, \mathrm{H}_{2} \mathrm{O}, 130^{\circ} \mathrm{C}, 3 \mathrm{~d} \\ & 84 \%\end{aligned}$

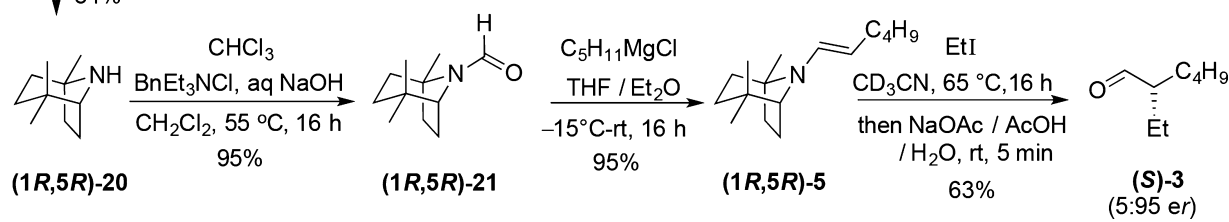



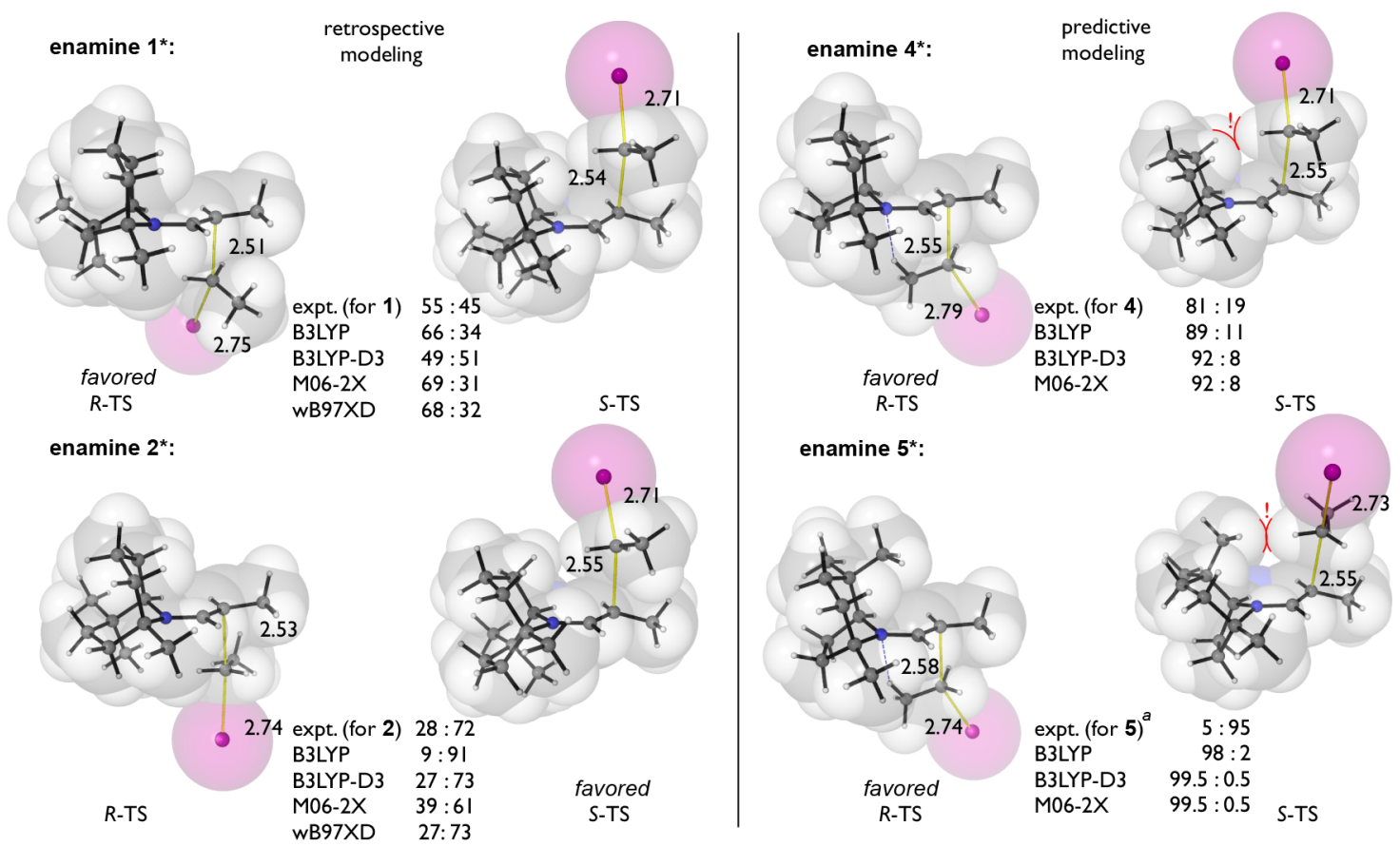

Figure 4. Computed stereoselectivities for the ethylation of enamines $1^{*}, 2^{*}, 4^{*}$, and $5^{*}$ with different density functionals. Distances $(\AA)$ refer to B3LYP TSs. The unfavorable overlap of van der Waals radii is highlighted. Model enamine $5^{*}$ is a pseudoenantiomer of experimental substrate 5: the predicted absolute sense of stereoinduction is therefore correctly opposite to experiment.

to a broad consensus in the levels of selectivity. Tighter transition structures were found with the dispersion-corrected methods vs B3LYP, in some cases with forming/breaking distances shorter by more than $0.1 \AA$. More pronounced nonbonding interactions arise, and consequently, higher computed levels of selectivity.

\section{CONCLUSION}

The first tropane-type derived enamines computationally predicted to show high levels of asymmetric induction on alkylation have been synthesized, and the experimentally observed ers are in good agreement with the DFT studies. The monomethyltropane derived enamine 4 illustrates the use of differing ring size (piperidine versus pyrrolidine in the $N$ bridged bicycle) as an unusual design element to bias $\pi$-facial selectivity with an electrophile. While undesired $\mathrm{N}$-alkylation became competitive with this system, the presence of an additional exo-methyl group in the six-membered ring (enamine 5) was sufficient to restore a synthetically useful yield (63\%) and provide the highest level of asymmetric induction for ethylation observed so far $(95: 5 \mathrm{er})$. This chemistry demonstrates the potential of the tropane scaffold as a useful chiral auxiliary for the synthesis of $\alpha$-alkylated aldehydes by nucleophilic substitution. Predictions of trends in enantioselectivity, which can be used synthetically to optimize levels of stereoinduction, are in this case relatively insensitive to the level of theory chosen. However, accurate predictions of the precise magnitude of enantioselectivity remain a continuing challenge.

\section{EXPERIMENTAL SECTION}

General Details. Where anhydrous conditions were required, reactions were performed using flame-dried glassware under an atmosphere of nitrogen. $\mathrm{C}_{6} \mathrm{H}_{6}, \mathrm{CH}_{2} \mathrm{Cl}_{2}, \mathrm{Et}_{2} \mathrm{O}, \mathrm{MeOH}, \mathrm{EtOH}$, pentane, and THF were dried over $4 \AA$ molecular sieves, then degassed and dried over activated alumina under nitrogen. $\mathrm{CD}_{3} \mathrm{CN}$ was purchased in glass ampules $(0.75 \mathrm{~mL})$, and $\mathrm{C}_{6} \mathrm{D}_{6}$ was purchased as a bottled reagent
$(1 \mathrm{~g})$; both were opened under an atmosphere of nitrogen and distilled over $\mathrm{CaH}_{2}$ immediately prior to use. EtI was passed through basic alumina immediately prior to use. All other reagents were used as received. Reactions were monitored by TLC using silica gel-coated aluminum-backed plates (Kieselgel $60 \mathrm{~F}_{254}$ ). The plates were visualized using UV light and developed in basic potassium permanganate, phosphomolybdic acid, or ninhydrin solutions. Column chromatography was performed using the solvent systems indicated. The stationary phase used was silica gel $(0.04-0.06 \mathrm{~mm}$ particle size, Kieselgel 60). Where silica gel is indicated as deactivated, this was carried out by stirring the silica gel overnight in $20 \% \mathrm{Et}_{3} \mathrm{~N}$ in petroleum ether. Petroleum ether refers to the fraction of light petrol boiling between 30 and $40{ }^{\circ} \mathrm{C}$. HPLC was performed using Daicel chiral columns and HPLC grade solvents. Melting points are uncorrected. Specific rotations $[\alpha]_{\lambda}^{T}$ were measured using a cell of path length $10 \mathrm{~cm}$, at $T=25{ }^{\circ} \mathrm{C}$, with $\lambda=589 \mathrm{~nm}$ (sodium $\mathrm{D}$ line), in the stated solvent, at a concentration $(c)$ given in $\mathrm{g} / 100 \mathrm{~mL}$, and are recorded in $10^{-1} \mathrm{deg} \mathrm{cm}^{2} \mathrm{~g}^{-1}$. IR spectra were recorded as either neat samples or thin films in $\mathrm{CH}_{2} \mathrm{Cl}_{2} / \mathrm{CHCl}_{3}$. The intensity of the peaks are recorded as strong $(\mathrm{s})$, medium $(\mathrm{m})$, or weak $(\mathrm{w})$ and prefixed with broad (br) where appropriate. ${ }^{1} \mathrm{H},{ }^{13} \mathrm{C}$ and ${ }^{77} \mathrm{Se}$ NMR spectra were recorded in $\mathrm{CDCl}_{3}$ (unless stated otherwise) at ambient temperature using either 400 or $500 \mathrm{MHz}$ spectrometers. Data are expressed as chemical shifts in parts per million (ppm) relative to residual chloroform and $\mathrm{CDCl}_{3}\left({ }^{1} \mathrm{H} \delta 7.27,{ }^{13} \mathrm{C} \delta 77.0\right.$ respectively), residual DMSO and DMSO- $d_{6}\left({ }^{1} \mathrm{H} \delta 2.50,{ }^{13} \mathrm{C} \delta 40.0\right.$, respectively) or residual benzene and $\mathrm{C}_{6} \mathrm{D}_{6}\left({ }^{1} \mathrm{H} \delta 7.16,{ }^{13} \mathrm{C} \delta 128.4\right.$, respectively) as the internal standard on the $\delta$ scale. The multiplicity of each signal is designated using the following abbreviations; s, singlet; br s, broad singlet; d, doublet; dd, doublet of doublets; ddd, doublet of doublet of doublets; dt, doublet of triplets; $\mathrm{t}$, triplet; $\mathrm{td}$, triplet of doublets; $\mathrm{m}$, multiplet. Where diastereoselectivity is quoted, this was determined from isolated, corresponding, signals of each diastereomer in the crude ${ }^{1} \mathrm{H}$ NMR. ${ }^{1} \mathrm{H}$ and ${ }^{13} \mathrm{C}$ NMR peak assignments were made using COSY, DEPT, and HSQC experiments. High-resolution mass spectra were obtained by ESI (MicroTOF); values are quoted as ratio of mass to charge $(\mathrm{m} / \mathrm{z})$ in Daltons, and relative intensities of assignable peaks observed are quoted as a percentage value. 
1-Methyltropane (1S,5R)-4 Synthesis. ( \pm )-8-Benzyl-1-methyl8-azabicyclo[3.2.1]octan-3-one (( \pm )-7). To a stirred solution of $\mathrm{NaOAc}(7.70 \mathrm{~g}, 94 \mathrm{mmol})$ in $\mathrm{H}_{2} \mathrm{O}(70 \mathrm{~mL})$ was added benzylamine $(2.50 \mathrm{~mL}, 23 \mathrm{mmol})$ followed immediately by concd $\mathrm{HCl}(2.00 \mathrm{~mL}$, $24 \mathrm{mmol}$ ), maintaining the reaction temperature below $10^{\circ} \mathrm{C}$. After 15 $\mathrm{min}$, acetone-1,3-dicarboxylic acid $(3.65 \mathrm{~g}, 25 \mathrm{mmol})$ was added to form a homogeneous reaction mixture $(\mathrm{pH} \sim 5)$, followed by dropwise addition of 4-oxopentanal $6^{19}(2.10 \mathrm{~g}, 21 \mathrm{mmol})$ over 10 $\min$. The reaction mixture was then warmed to $40{ }^{\circ} \mathrm{C}$. After $7 \mathrm{~h}$, the reaction mixture was cooled to $15{ }^{\circ} \mathrm{C}$, the $\mathrm{pH}$ adjusted to $\sim 10$ with $50 \%$ aq $\mathrm{NaOH}(\sim 5 \mathrm{~mL})$, and the reaction mixture extracted with $\mathrm{CH}_{2} \mathrm{Cl}_{2}(3 \times 120 \mathrm{~mL})$. The combined organic layers were dried $\left(\mathrm{Na}_{2} \mathrm{SO}_{4}\right)$ and evaporated under reduced pressure. Purification of the residue by column chromatography $\left(\mathrm{Et}_{3} \mathrm{~N}\right.$-deactivated $\mathrm{SiO}_{2}$, gradient elution $0-4 \% \mathrm{EtOAc}$ in petroleum ether containing $\left.2 \% \mathrm{Et}_{3} \mathrm{~N}\right)$ gave tropinone $( \pm)-7$ as a yellow oil $(2.70 \mathrm{~g}, 56 \%): R_{f}=0.15$ (4\% EtOAc in petroleum ether); IR (neat) $\left(\mathrm{cm}^{-1}\right) 1712 \mathrm{~s}(\mathrm{C}=\mathrm{O}) ;{ }^{1} \mathrm{H}$ NMR (400 $\mathrm{MHz}) \delta 7.35$ (d, $2 \mathrm{H}, J=7 \mathrm{~Hz}, \mathrm{Ar}$ (ortho)), 7.29-7.25 (m, $2 \mathrm{H}, \mathrm{Ar}$ (meta)), 7.21-7.18 (m, 1H, Ar (para)), $3.84(\mathrm{~d}, 1 \mathrm{H}, J=13 \mathrm{~Hz}$, $\mathrm{CH}_{\mathrm{A}} \mathrm{CH}_{\mathrm{B}} \mathrm{Ph}$ ), $3.67\left(\mathrm{~d}, 1 \mathrm{H}, J=13 \mathrm{~Hz}, \mathrm{CH}_{\mathrm{A}} \mathrm{CH}_{\mathrm{B}} \mathrm{Ph}\right.$ ), 3.38 (ddd, $1 \mathrm{H}, J=$ $7 \mathrm{~Hz}, J=5 \mathrm{~Hz}, J=2 \mathrm{~Hz}, C H N B n), 2.60(\mathrm{~d}, 1 \mathrm{H}, J=16 \mathrm{~Hz}$, $\left.\mathrm{COCH}_{\mathrm{A}} \mathrm{CH}_{\mathrm{B}} \mathrm{CHN}\right), 2.46\left(\mathrm{~d}, 1 \mathrm{H}, J=16 \mathrm{~Hz}, \mathrm{COCH}_{\mathrm{A}} \mathrm{CH}_{\mathrm{B}} \mathrm{CCH}_{3}\right), 2.13$ $\left(\mathrm{dd}, 1 \mathrm{H}, J=16 \mathrm{~Hz}, J=2 \mathrm{~Hz}, \mathrm{COCH}_{\mathrm{A}} \mathrm{CH}_{\mathrm{B}} \mathrm{CCH}_{3}\right), 1.96(\mathrm{dt}, 1 \mathrm{H}, J=16$ $\left.\mathrm{Hz}, J=2 \mathrm{~Hz}, \mathrm{COCH}_{\mathrm{A}} \mathrm{CH}_{\mathrm{B}} \mathrm{CHN}\right), 1.92-1.82(\mathrm{~m}, 1 \mathrm{H}$, $\left.\mathrm{CHCH}_{\mathrm{A}} \mathrm{CH}_{\mathrm{B}} \mathrm{CH}_{2}\right), 1.70-1.66\left(\mathrm{~m}, 2 \mathrm{H}, \mathrm{CHCH}_{2} \mathrm{CH}_{2}\right), 1.41-1.34(\mathrm{~m}$, $\left.1 \mathrm{H}, \mathrm{CHCH}_{\mathrm{A}} \mathrm{CH}_{\mathrm{B}} \mathrm{CH}_{2}\right), 1.23\left(\mathrm{~s}, 3 \mathrm{H}, \mathrm{CH}_{3}\right) ;{ }^{13} \mathrm{C} \mathrm{NMR}(101 \mathrm{MHz}) \delta$ 210.2 (CO), 139.7 (Ar (ipso)), 128.4 (Ar (ortho), $\mathrm{Ar}$ (meta)), 127.0 (Ar (para)), $62.6\left(\mathrm{NCCH}_{3}\right), 56.8(\mathrm{CH}), 50.8\left(\mathrm{COCH}_{2} \mathrm{CCH}_{3}\right), 48.1$ $\left(\mathrm{NCH}_{2} \mathrm{Ph}\right), 42.8\left(\mathrm{COCH}_{2} \mathrm{CH}\right), 36.6\left(\mathrm{CHCH}_{2} \mathrm{CH}_{2}\right), 27.6$ $\left(\mathrm{CHCH}_{2} \mathrm{CH}_{2}\right), 24.8\left(\mathrm{CH}_{3}\right)$; HRMS (ESI/TOF) $\mathrm{m} / z[\mathrm{M}+\mathrm{H}]^{+}$calcd for $\mathrm{C}_{15} \mathrm{H}_{20} \mathrm{NO} 230.1539$; found 230.1540 .

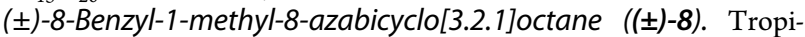
none $( \pm)-7(1.83 \mathrm{~g}, 8.0 \mathrm{mmol})$ and hydrazine monohydrate $(2.88 \mathrm{~g}$, $57.5 \mathrm{mmol})$ were added to a stirred solution of powdered $\mathrm{KOH}(7.06$ $\mathrm{g}, 126 \mathrm{mmol})$ in diethylene glycol $(17 \mathrm{~mL})$ at $\mathrm{rt}$. The mixture was then heated to $220{ }^{\circ} \mathrm{C}$. After $24 \mathrm{~h}$, the reaction mixture was cooled to rt, diluted with $\mathrm{H}_{2} \mathrm{O}(120 \mathrm{~mL})$, and extracted with $\mathrm{Et}_{2} \mathrm{O}(3 \times 120 \mathrm{~mL})$. The combined organic layers were dried $\left(\mathrm{MgSO}_{4}\right)$ and evaporated under reduced pressure. Purification of the residue by column chromatography $\left(\mathrm{SiO}_{2}\right.$, gradient elution $0-2 \%$ EtOAc in petroleum ether containing $\left.2 \% \mathrm{Et}_{3} \mathrm{~N}\right)$ gave tropane $( \pm)-8$ as a pale yellow oil (1.52 g, 88\%): $R_{f}=0.24$ (4\% EtOAc in petroleum ether); ${ }^{1} \mathrm{H}$ NMR $(400 \mathrm{MHz}) \delta 7.40(\mathrm{~d}, 2 \mathrm{H}, J=7.5 \mathrm{~Hz}, \mathrm{Ar}($ ortho $)), 7.33-7.29(\mathrm{~m}, 2 \mathrm{H}$, $\operatorname{Ar}($ meta $)), 7.24-7.21$ (m, $1 \mathrm{H}, \mathrm{Ar}$ (para)), $3.86(\mathrm{~d}, 1 \mathrm{H}, J=14 \mathrm{~Hz}$, $\left.\mathrm{CH}_{\mathrm{A}} \mathrm{H}_{\mathrm{B}} \mathrm{Ph}\right), 3.59\left(\mathrm{~d}, 1 \mathrm{H}, J=14 \mathrm{~Hz}, \mathrm{CH}_{\mathrm{A}} \mathrm{H}_{\mathrm{B}} \mathrm{Ph}\right), 3.13-3.12(\mathrm{~m}, 1 \mathrm{H}$, CHNBn), $1.93-1.50\left(\mathrm{~m}, 8 \mathrm{H}, 3 \times \mathrm{CH}_{2}, 2 \times \mathrm{CH}_{\mathrm{A}} \mathrm{H}_{\mathrm{B}}\right), 1.19$ (dd, $1 \mathrm{H}, J=$ $\left.12 \mathrm{~Hz}, J=4 \mathrm{~Hz}, \mathrm{CH}_{\mathrm{A}} \mathrm{H}_{\mathrm{B}}\right), 1.16\left(\mathrm{~s}, 3 \mathrm{H}, \mathrm{CH}_{3}\right), 1.07-1.01(\mathrm{~m}, 1 \mathrm{H}$, $\left.\mathrm{CH}_{\mathrm{A}} \mathrm{H}_{\mathrm{B}}\right) ;{ }^{13} \mathrm{C}$ NMR $(101 \mathrm{MHz}) \delta 141.2$ (Ar (ipso)), $128.6(\mathrm{Ar}$ (ortho)), 128.0 (Ar (meta)), 126.3 (Ar (para)), $60.5\left(\mathrm{CCH}_{3}\right), 56.7$ $(\mathrm{CH}), 48.6\left(\mathrm{NCH}_{2} \mathrm{Ph}\right), 35.7\left(\mathrm{CH}_{2}\right), 33.1\left(\mathrm{CH}_{2}\right), 27.1\left(\mathrm{CH}_{2}\right), 25.5$ $\left(\mathrm{CH}_{3}\right), 24.7\left(\mathrm{CH}_{2}\right), 18.4\left(\mathrm{CH}_{2}\right)$; HRMS (ESI/TOF) $\mathrm{m} / z[\mathrm{M}+\mathrm{H}]^{+}$ calcd for $\mathrm{C}_{15} \mathrm{H}_{22} \mathrm{~N}$ 216.1747; found 216.1748 .

(士)-1-Methyl-8-azabicyclo[3.2.1]octane (( \pm )-9). Pd/C (10 wt \%, $766 \mathrm{mg}, 0.72 \mathrm{mmol}$ ) was added to a stirred solution of tropane $( \pm)-8$ $(1.54 \mathrm{~g}, 7.15 \mathrm{mmol})$ in $\mathrm{MeOH}(200 \mathrm{~mL})$ at rt. Hydrogen gas was bubbled through the solution for $1 \mathrm{~min}$ and the mixture was then vigorously stirred under a hydrogen atmosphere for $24 \mathrm{~h}$. The catalyst was removed by filtration through Celite and $2 \mathrm{M} \mathrm{HCl}$ in $\mathrm{Et}_{2} \mathrm{O}$ (19 $\mathrm{mL}$ ) was added to the filtrate. The filtrate was evaporated under reduced pressure and the residue was washed with $\mathrm{CH}_{2} \mathrm{Cl}_{2}(5 \times 20$ $\mathrm{mL})$ to give tropane hydrochloride salt as a peach solid (1.15 g) (mp $\left.220-222{ }^{\circ} \mathrm{C}\right)$. This salt $(1.15 \mathrm{~g}, 7.20 \mathrm{mmol})$ was suspended in $\mathrm{Et}_{2} \mathrm{O}$ $(20 \mathrm{~mL})$ and washed with $3 \mathrm{M}$ aq $\mathrm{NaOH}(20 \mathrm{~mL})$. The ethereal layer was separated and the aq phase back-extracted with $\mathrm{Et}_{2} \mathrm{O}(3 \times 20 \mathrm{~mL})$. The combined organic layers were dried $\left(\mathrm{Na}_{2} \mathrm{SO}_{4}\right)$ and concentrated by careful evaporation $\left(228 \mathrm{~mm}, 35^{\circ} \mathrm{C}\right)$, gave 1-methytropane $( \pm)-9$ as a clear oil (894 mg, quant): IR (neat) $\left(\mathrm{cm}^{-1}\right) 3658 \mathrm{w}(\mathrm{N}-\mathrm{H}) ;{ }^{1} \mathrm{H}$ NMR $(400 \mathrm{MHz}) \delta 3.45-3.44(\mathrm{~m}, 1 \mathrm{H}, \mathrm{NCH}), 1.90-1.33(\mathrm{~m}, 11 \mathrm{H}, 5$ $\times \mathrm{CH}_{2}$ and $\left.\mathrm{NH}\right), 1.15\left(\mathrm{~s}, 3 \mathrm{H}, \mathrm{NC}\left(\mathrm{CH}_{3}\right)\right) ;{ }^{13} \mathrm{C} \mathrm{NMR}(101 \mathrm{MHz}) \delta$ $59.4\left(\mathrm{NC}\left(\mathrm{CH}_{3}\right)\right), 55.9(\mathrm{NCH}), 39.1\left(\mathrm{CH}_{2}\right), 35.9\left(\mathrm{CH}_{2}\right), 32.0\left(\mathrm{CH}_{2}\right)$,
$30.7\left(\mathrm{CH}_{2}\right), 27.5\left(\mathrm{CH}_{3}\right), 18.6\left(\mathrm{CH}_{2}\right)$; HRMS (ESI/TOF) $m / z[\mathrm{M}$ $+\mathrm{H}]^{+}$calcd for $\mathrm{C}_{8} \mathrm{H}_{16} \mathrm{~N}$ 126.1277; found 126.1277.

tert-Butyl-((S)-1-((1S,5R)-1-methyl-8-azabicyclo[3.2.1]octan-8-yl)1-oxo-3-phenylpropan-2-yl)carbamate $((S, 1 S, 5 R)-10)$ and tertButyl-((S)-1-((1R,5S)-1-methyl-8-azabicyclo[3.2.1]octan-8-yl)-1-oxo3-phenylpropan-2-yl)carbamate ((S,1R,5S)-10). To a stirred solution of 1-methyltropane $( \pm)-9(1.50 \mathrm{~g}, 12.0 \mathrm{mmol})$ in $\mathrm{CH}_{2} \mathrm{Cl}_{2}(100 \mathrm{~mL})$ at $0{ }^{\circ} \mathrm{C}$ was added $i \operatorname{Pr}_{2} \mathrm{EtN}(3.43 \mathrm{~g}, 26.5 \mathrm{mmol}), N$-Boc-L-Phe-OH $(3.50$ g, $13.2 \mathrm{mmol}$ ), and bis(2-oxo-3-oxazolidinyl)phosphinic chloride (3.35 g, $13.2 \mathrm{mmol}$ ). The reaction mixture was kept in a refrigerator at $0-4$ ${ }^{\circ} \mathrm{C}$ for $5 \mathrm{~d}$ [TLC monitoring (50\% EtOAc in petroleum ether)]. After this time, the reaction mixture was diluted with ice-cold EtOAc $(750$ $\mathrm{mL})$, washed with ice-cold $5 \%$ aq $\mathrm{HCl}(500 \mathrm{~mL})$ and $5 \%$ aq $\mathrm{NaHCO}_{3}$ $(500 \mathrm{~mL})$. The combined organic layers were dried $\left(\mathrm{Na}_{2} \mathrm{SO}_{4}\right)$ and evaporated under reduced pressure. Purification of the residue by column chromatography $\left(\mathrm{SiO}_{2}\right.$, gradient elution $0-10 \% \mathrm{EtOAc}$ in petroleum ether) gave Boc-protected $\alpha$-amino amide $(S, 1 S, 5 R)-10$ as a colorless oil $(1.32 \mathrm{~g})$, followed by a mixed fraction $(1.04 \mathrm{~g})$, and finally Boc-protected $\alpha$-amino amide $(S, 1 R, 5 S)$-10 as a white solid $(1.38 \mathrm{~g})$ (3.74 g total product, 1:1 dr, 84\%);

Data for $(S, 1 S, 5 R)-10: R_{f}=0.32(10 \%$ EtOAc in petroleum ether); $[\alpha]_{\mathrm{D}}^{25}+34.2\left(c 0.5, \mathrm{CHCl}_{3}\right)$; IR (film) $\left(\mathrm{cm}^{-1}\right) 3342 \mathrm{brm}(\mathrm{N}-\mathrm{H}), 1638$ m (CO-NH); ${ }^{1} \mathrm{H}$ NMR (400 MHz) $\delta 7.27-7.21(\mathrm{~m}, 5 \mathrm{H}, \mathrm{Ph}), 5.50$ $(\mathrm{d}, 1 \mathrm{H}, J=8.0 \mathrm{~Hz}, \mathrm{NH}), 4.71(\mathrm{dd}, 1 \mathrm{H}, J=13.5 \mathrm{~Hz}, 8.5 \mathrm{~Hz}, \mathrm{NHCH})$, $3.91(\mathrm{~d}, 1 \mathrm{H}, J=7.0 \mathrm{~Hz}, \mathrm{NCH}), 3.03(\mathrm{dd}, 1 \mathrm{H}, J=13.0 \mathrm{~Hz}, 5.0 \mathrm{~Hz}$, $\left.\mathrm{PhCH}_{\mathrm{A}} \mathrm{CH}_{\mathrm{B}}\right), 2.90\left(\mathrm{dd}, 1 \mathrm{H}, J=13.0 \mathrm{~Hz}, 9.0 \mathrm{~Hz}, \mathrm{PhCH}_{\mathrm{A}} \mathrm{CH}_{\mathrm{B}}\right), 1.95-$ $1.89\left(\mathrm{~m}, 1 \mathrm{H}, \mathrm{CH}_{\mathrm{A}} \mathrm{CH}_{\mathrm{B}}\right), 1.74-1.20\left(\mathrm{~m}, 9 \mathrm{H}, 4 \times \mathrm{CH}_{2}\right.$ and $\left.\mathrm{CH}_{\mathrm{A}} \mathrm{CH}_{\mathrm{B}}\right)$, $1.55\left(\mathrm{~s}, 3 \mathrm{H}, \mathrm{CH}_{3}\right), 1.44(\mathrm{~s}, 9 \mathrm{H}, t-\mathrm{Bu}) ;{ }^{13} \mathrm{C}$ NMR $(101 \mathrm{MHz}) \delta 169.1$ $(\mathrm{NHCHC}=\mathrm{O}), 155.0(\mathrm{NHC}=\mathrm{O}), 136.7(\mathrm{Ar}($ ipso $)), 129.5(\mathrm{Ar}$ (ortho)), 128.0 (Ar (meta)), 126.6 (Ar (para)), $79.2\left(\mathrm{C}\left(\mathrm{CH}_{3}\right)_{3}\right), 63.3$ $\left(\mathrm{NC}\left(\mathrm{CH}_{3}\right)\right), 58.8(\mathrm{NCH}), 53.1(\mathrm{NHCH}), 40.8\left(\mathrm{CH}_{2} \mathrm{Ph}\right), 37.1\left(\mathrm{CH}_{2}\right)$, $36.2\left(\mathrm{CH}_{2}\right), 32.7\left(\mathrm{CH}_{3}\right), 28.2\left(\mathrm{C}\left(\mathrm{CH}_{3}\right)_{3}\right), 26.1\left(\mathrm{CH}_{2}\right), 25.5\left(\mathrm{CH}_{2}\right)$, $17.9\left(\mathrm{CH}_{2}\right)$; HRMS (ESI/TOF) $m / z[\mathrm{M}+\mathrm{H}]^{+}$calcd for $\mathrm{C}_{22} \mathrm{H}_{33} \mathrm{~N}_{2} \mathrm{O}_{3}$ 373.2486; found 373.2482.

Data for $(S, 1 R, 5 S)-10: \mathrm{mp} 76-78{ }^{\circ} \mathrm{C} ; R_{f}=0.29$ (10\% EtOAc in petroleum ether); $[\alpha]_{\mathrm{D}}^{25}-26.2\left(\right.$ c $\left.0.8, \mathrm{CHCl}_{3}\right)$; IR (neat) $\left(\mathrm{cm}^{-1}\right) 3327$ brm $(\mathrm{N}-\mathrm{H}), 1636 \mathrm{w}(\mathrm{CO}-\mathrm{NH}) ;{ }^{1} \mathrm{H}$ NMR $(400 \mathrm{MHz}) \delta 7.21-7.10$ $(\mathrm{m}, 5 \mathrm{H}, \mathrm{Ph}), 5.19(\mathrm{~d}, 1 \mathrm{H}, J=9 \mathrm{~Hz}, \mathrm{NH}), 4.59(\mathrm{~d}, 1 \mathrm{H}, J=7 \mathrm{~Hz}$, $\mathrm{NCH}), 4.31($ br s, $1 \mathrm{H}, \mathrm{NCH}), 3.12-3.07\left(\mathrm{~m}, 1 \mathrm{H}, \mathrm{PhCH}_{\mathrm{A}} \mathrm{CH}_{\mathrm{B}}\right), 2.80-$ $2.75\left(\mathrm{~m}, 1 \mathrm{H}, \mathrm{PhCH}_{\mathrm{A}} \mathrm{CH}_{\mathrm{B}}\right), 1.87-1.85\left(\mathrm{~m}, 1 \mathrm{H}, \mathrm{CH}_{\mathrm{A}} \mathrm{CH}_{\mathrm{B}}\right), 1.72-1.11$ $\left(\mathrm{m}, 9 \mathrm{H}, 4 \times \mathrm{CH}_{2}\right.$ and $\left.\mathrm{CH}_{\mathrm{A}} \mathrm{CH}_{\mathrm{B}}\right), 1.65\left(\mathrm{~s}, 3 \mathrm{H}, \mathrm{CH}_{3}\right), 1.31(\mathrm{~s}, 9 \mathrm{H}, t-$ $\mathrm{Bu}) ;{ }^{13} \mathrm{C}$ NMR $(101 \mathrm{MHz}) \delta 168.9(\mathrm{NHCHC}=\mathrm{O}), 155.0(\mathrm{NHC}=$ O), 137.2 (Ar (ipso)), 129.8 (Ar (ortho)), 128.2 (Ar (meta)), 126.5 (Ar (para)), $\left.79.4\left(\mathrm{C} \mathrm{CH}_{3}\right)_{3}\right), 63.8\left(\mathrm{NC}\left(\mathrm{CH}_{3}\right)\right), 57.9(\mathrm{NCH}), 53.5$ $(\mathrm{NHCH}) 39.2\left(\mathrm{CH}_{2} \mathrm{Ph}\right), 37.4\left(\mathrm{CH}_{2}\right), 36.8\left(\mathrm{CH}_{2}\right), 32.0\left(\mathrm{CH}_{3}\right), 28.2$ $\left(\mathrm{C}\left(\mathrm{CH}_{3}\right)_{3}\right), 26.5\left(\mathrm{CH}_{2}\right), 26.4\left(\mathrm{CH}_{2}\right), 18.0\left(\mathrm{CH}_{2}\right) ; \mathrm{HRMS}$ (ESI/TOF) $m / z[\mathrm{M}+\mathrm{H}]^{+}$calcd for $\mathrm{C}_{22} \mathrm{H}_{33} \mathrm{~N}_{2} \mathrm{O}_{3}$ 373.2486; found 373.2488.

(+)-(S)-2-Amino-1-((1S,5R)-1-methyl-8-azabicyclo[3.2.1]octan-8yl)-3-phenylpropan-1-one ((S, 1S,5R)-11). Anhydrous TFA (7 mL) was added to a stirred solution of Boc-protected $\alpha$-amino amide $(S, 1 S, 5 R)-10(1.0 \mathrm{~g}, 2.7 \mathrm{mmol})$ in $\mathrm{CH}_{2} \mathrm{Cl}_{2}(30 \mathrm{~mL})$ at rt. After $1 \mathrm{~h}$, the mixture was evaporated under reduced pressure and the residue dissolved in $\mathrm{CHCl}_{3}(30 \mathrm{~mL})$. The resulting solution was washed with $10 \%$ aq $\mathrm{Na}_{2} \mathrm{CO}_{3}(50 \mathrm{~mL})$. The aq layer was separated and backextracted with $\mathrm{CHCl}_{3}(2 \times 30 \mathrm{~mL})$. The combined organic layers were dried $\left(\mathrm{Na}_{2} \mathrm{SO}_{4}\right)$ and evaporated under reduced pressure. Purification of the residue by column chromatography $\left(\mathrm{SiO}_{2}\right.$, gradient elution 5$10 \% \mathrm{MeOH}$ in EtOAc) gave $\alpha$-amino amide $(S, 1 S, 5 R)-11$ as a pale oil $(0.67 \mathrm{~g}, 90 \%): R_{f}=0.45\left(10 \% \mathrm{MeOH}\right.$ in EtOAc); $[\alpha]_{\mathrm{D}}^{25}+71.3(c=1.0$, $\left.\mathrm{CHCl}_{3}\right)$; IR (neat) $\left(\mathrm{cm}^{-1}\right) 3658 \mathrm{w}(\mathrm{N}-\mathrm{H}), 1636 \mathrm{w}(\mathrm{CO}-\mathrm{NH}) ;{ }^{1} \mathrm{H}$ NMR $(400 \mathrm{MHz}) \delta 7.24-7.13(\mathrm{~m}, 5 \mathrm{H}, \mathrm{Ph}), 3.90(\mathrm{br}, \mathrm{s}, 1 \mathrm{H}$, $\mathrm{CONCH}), 3.79\left(\mathrm{t}, J=7.2 \mathrm{~Hz}, 1 \mathrm{H}, \mathrm{NH}_{2} \mathrm{CH}\right), 2.84-2.75(\mathrm{~m}, 2 \mathrm{H}$ $\left.\mathrm{PhCH}_{2}\right), 1.93-1.25\left(\mathrm{~m}, 10 \mathrm{H}, 5 \times \mathrm{CH}_{2}\right), 1.53\left(\mathrm{~s}, 3 \mathrm{H}, \mathrm{CH}_{3}\right) ;{ }^{13} \mathrm{C} \mathrm{NMR}$ (101 MHz) $\delta 172.4(\mathrm{C}=\mathrm{O}), 137.7$ (Ar (ipso)), 129.4 (Ar (ortho)), 128.3 (Ar (meta)), 126.6 (Ar (para)), 63.5 (CONCH), 58.3 $\left(\mathrm{NC}\left(\mathrm{CH}_{3}\right)\right), 54.4\left(\mathrm{H}_{2} \mathrm{NCH}\right), 43.5\left(\mathrm{CH}_{2}\right), 37.2\left(\mathrm{PhCH}_{2}\right), 36.4$ $\left(\mathrm{CH}_{2}\right), 32.9\left(\mathrm{CH}_{3}\right), 26.4\left(\mathrm{CH}_{2}\right), 25.7\left(\mathrm{CH}_{2}\right), 18.0\left(\mathrm{CH}_{2}\right)$; HRMS (ESI/TOF) $m / z[\mathrm{M}+\mathrm{H}]^{+}$calcd for $\mathrm{C}_{17} \mathrm{H}_{25} \mathrm{~N}_{2} \mathrm{O}$ 273.1961; found 273.1961. 
(+)-(1S,5R)-1-Methyl-8-azabicyclo[3.2.1]octane ((1S,5R)-9). PhNCS (334 mg, $2.5 \mathrm{mmol}$ ) was added to a stirred solution of $\alpha$ amino amide $(S, 1 S, 5 R)-11(657 \mathrm{mg}, 2.4 \mathrm{mmol})$ in $\mathrm{CH}_{2} \mathrm{Cl}_{2}(40 \mathrm{~mL})$ at rt. A distillation head, condenser, and receiver flask were connected to the reaction vessel, and $\mathrm{CH}_{2} \mathrm{Cl}_{2}$ was removed over an oil bath (100 ${ }^{\circ} \mathrm{C}$ ). The distillate was recombined with the contents of the reaction vessel, and the distillation procedure was repeated until $\alpha$-amino amide $(S, 1 S, 5 R)-11$ had been consumed (determined by TLC $(10 \% \mathrm{MeOH}$ in EtOAc)). Upon completion, the mixture was concentrated to dryness and TFA $(20 \mathrm{~mL})$ added to the residue. The resulting solution was heated at $50{ }^{\circ} \mathrm{C}$ for $20 \mathrm{~min}$. After this time, the reaction mixture was evaporated under reduced pressure and the residue dissolved in $\mathrm{CHCl}_{3}(100 \mathrm{~mL})$. This solution was partitioned with $\mathrm{H}_{2} \mathrm{O}(100 \mathrm{~mL})$, and the aq layer was separated and basified with $3 \mathrm{M}$ aq $\mathrm{NaOH}(100$ $\mathrm{mL})$. The resulting suspension was washed with $\mathrm{Et}_{2} \mathrm{O}(5 \times 100 \mathrm{~mL})$. The combined organic layers were dried $\left(\mathrm{Na}_{2} \mathrm{SO}_{4}\right)$ and carefully evaporated under reduced pressure to give 1-methyltropane $(\mathbf{1 S}, \mathbf{5 R})-\mathbf{9}$ as a clear oil $(276 \mathrm{mg}, 93 \%):[\alpha]_{\mathrm{D}}^{25}+8.5\left(c 0.4, \mathrm{CHCl}_{3}\right)$; other data as above.

(+)-(S)-2-Amino-1-((1R,5S)-1-methyl-8-azabicyclo[3.2.1]octan-8yl)-3-phenylpropan-1-one TFA Salt $(S, 1 R, 5 S)-11 \cdot T F A)$. Anhydrous TFA $(7 \mathrm{~mL})$ was added to a stirred solution of Boc-protected $\alpha$-amino amide $(S, 1 R, 5 S)-10(1.0 \mathrm{~g}, 2.7 \mathrm{mmol})$ in $\mathrm{CH}_{2} \mathrm{Cl}_{2}(30 \mathrm{~mL})$ at rt. After $15 \mathrm{~min}$, the mixture was evaporated under reduced pressure and the residue was washed with $\mathrm{CH}_{2} \mathrm{Cl}_{2}(3 \times 20 \mathrm{~mL})$ to give TFA salt $(S, 1 R, 5 S)-11 \cdot T F A$ as colorless crystals $(1.00 \mathrm{~g}, 98 \%): \mathrm{mp} 186-188$ ${ }^{\circ} \mathrm{C}$; IR (film) $\left(\mathrm{cm}^{-1}\right) 1674 \mathrm{~s}(\mathrm{CO}-\mathrm{N}) ;{ }^{1} \mathrm{H}$ NMR (400 MHz, DMSO$\left.d_{6}\right) \delta 8.19\left(\mathrm{~s}, 3 \mathrm{H}, \mathrm{NH}_{3} \mathrm{COOCF}_{3}\right), 7.36-7.26(\mathrm{~m}, 5 \mathrm{H}, \mathrm{Ph}), 4.39-4.36$ (m, 1H, $\mathrm{NH}_{3} \mathrm{CH}$ ), 4.29 (br, s, $\left.1 \mathrm{H}, \mathrm{CONCH}\right), 3.09$ (dd, $J=13.0 \mathrm{~Hz}, J$ $\left.=8.5 \mathrm{~Hz}, 1 \mathrm{H}, \mathrm{PhCH}_{\mathrm{A}} \mathrm{CH}_{\mathrm{B}}\right), 2.93(\mathrm{dd}, J=13.0 \mathrm{~Hz}, J=5.5 \mathrm{~Hz}, 1 \mathrm{H}$, $\left.\mathrm{PhCH}_{\mathrm{A}} \mathrm{CH}_{\mathrm{B}}\right), 1.89-1.09\left(\mathrm{~m}, 9 \mathrm{H}, 4 \times \mathrm{CH}_{2}\right.$ and $\left.\mathrm{CH}_{\mathrm{A}} \mathrm{CH}_{\mathrm{B}}\right), 1.56(\mathrm{~s}$, $\left.3 \mathrm{H}, \mathrm{CH}_{3}\right), 0.32\left(\mathrm{t}, J=13.0 \mathrm{~Hz}, 1 \mathrm{H}, \mathrm{CH}_{\mathrm{A}} \mathrm{CH}_{\mathrm{B}}\right) ;{ }^{13} \mathrm{C} \mathrm{NMR}(101 \mathrm{MHz}$, DMSO-d $\left.{ }_{6}\right) \delta 165.1(\mathrm{C}=\mathrm{O}), 158.8\left(\mathrm{COOCF}_{3}\right), 158.5\left(\mathrm{COOCF}_{3}\right)$, 135.6 (Ar (ipso)), 130.4 (Ar (ortho)), 129.1 (Ar (meta)), 127.7 (Ar (para)), $64.2(\mathrm{CONCH}), 57.9\left(\mathrm{NC}\left(\mathrm{CH}_{3}\right)\right), 55.4\left(\mathrm{H}_{2} \mathrm{NCH}\right), 52.3$ $\left(\mathrm{CH}_{2}\right), 37.7\left(\mathrm{PhCH}_{2}\right), 37.2\left(\mathrm{CH}_{2}\right), 36.6\left(\mathrm{CH}_{3}\right), 31.8\left(\mathrm{CH}_{2}\right), 26.6$ $\left(\mathrm{CH}_{2}\right), 18.1\left(\mathrm{CH}_{2}\right)$; HRMS (ESI/TOF) $\mathrm{m} / z[\mathrm{M}+\mathrm{H}]^{+}$calcd for $\mathrm{C}_{17} \mathrm{H}_{25} \mathrm{~N}_{2} \mathrm{O} 273.1961$; found 273.1959 .

General Procedure for Formamide Synthesis. (-)-((1S,5R)-1Methyl-8-azabicyclo[3.2.1]octane-8-carbaldehyde ((1S,5R)-12). 12.5 M Aq NaOH $(3.3 \mathrm{~mL})$ was added to a stirred mixture of tropane $(\mathbf{1 S}, 5 R)-9(432 \mathrm{mg}, 3.5 \mathrm{mmol}), \mathrm{BnEt}_{3} \mathrm{NCl}(300 \mathrm{mg}, 1.58$ $\mathrm{mmol}$ ) and $\mathrm{CHCl}_{3}(2.2 \mathrm{~mL}, 0.03 \mathrm{~mol})$, in $\mathrm{CH}_{2} \mathrm{Cl}_{2}(9.5 \mathrm{~mL})$. The reaction mixture was then heated at reflux for $24 \mathrm{~h}$, then diluted with $\mathrm{H}_{2} \mathrm{O}(45 \mathrm{~mL})$, and extracted with $\mathrm{CH}_{2} \mathrm{Cl}_{2}(3 \times 20 \mathrm{~mL})$. The combined organic layers were washed with brine $(3 \times 30 \mathrm{~mL})$, dried $\left(\mathrm{MgSO}_{4}\right)$ and evaporated under reduced pressure. Purification of the residue by bulb-to-bulb distillation gave formamide $(\mathbf{1 S , 5 R})-\mathbf{1 2}$ as a clear oil (498 mg, 93\%): $[\alpha]_{\mathrm{D}}^{25}-83.9\left(c 0.85, \mathrm{CHCl}_{3}\right)$ : bp $140-150{ }^{\circ} \mathrm{C}$ $(7.6 \mathrm{~mm})$; IR (film) $\left(\mathrm{cm}^{-1}\right) 1657 \mathrm{~s}(\mathrm{C}=\mathrm{O}) ;{ }^{1} \mathrm{H}$ NMR $(400 \mathrm{MHz}) \delta$ $8.04(\mathrm{~s}, 1 \mathrm{H}, \mathrm{CHO}), 4.62(\mathrm{~d}, 1 \mathrm{H}, J=4 \mathrm{~Hz}, \mathrm{NCH}), 1.87-1.80(\mathrm{~m}, 2 \mathrm{H}$, $\left.2 \times \mathrm{CH}_{\mathrm{A}} \mathrm{H}_{\mathrm{B}}\right), 1.75-1.54\left(\mathrm{~m}, 6 \mathrm{H}, 3 \times \mathrm{CH}_{2}\right), 1.45-1.41(\mathrm{~m}, 2 \mathrm{H}, 2 \mathrm{x}$ $\left.\mathrm{CH}_{\mathrm{A}} \mathrm{H}_{\mathrm{B}}\right), 1.36\left(\mathrm{~s}, 3 \mathrm{H}, \mathrm{CH}_{3}\right) ;{ }^{13} \mathrm{C} \mathrm{NMR}(101 \mathrm{MHz}) \delta 156.3(\mathrm{C}=\mathrm{O})$, $60.6\left(\mathrm{NC}\left(\mathrm{CH}_{3}\right)\right), 52.0(\mathrm{NCH}), 41.0\left(\mathrm{CH}_{2}\right), 36.3\left(\mathrm{CH}_{2}\right), 30.2\left(\mathrm{CH}_{2}\right)$, $26.3\left(\mathrm{C}\left(\mathrm{CH}_{3}\right)_{2}\right), 23.5\left(\mathrm{CH}_{3}\right), 18.1\left(\mathrm{CH}_{3}\right)$; HRMS (ESI/TOF) $\mathrm{m} / \mathrm{z}$ $[\mathrm{M}+\mathrm{H}]^{+}$calcd for $\mathrm{C}_{9} \mathrm{H}_{16} \mathrm{NO}$ 154.1226; found 154.1226.

General Procedure for Enamine Synthesis. (1S,5R)-8-((E)-Hex1-en-1-yl)-1-methyl-8-azabicyclo[3.2.1]octane ((1S,5R)-4). Pentylmagnesium chloride $(1.33 \mathrm{~mL}, 2.0 \mathrm{M}$ in THF, $2.66 \mathrm{mmol})$ was added to a stirred solution of formamide $(\mathbf{1 S}, \mathbf{5 R})-12(310 \mathrm{mg}, 2.02$ $\mathrm{mmol})$ in $\mathrm{Et}_{2} \mathrm{O}(1.7 \mathrm{~mL})$ at -15 to $-20{ }^{\circ} \mathrm{C}$. After 15 min, the reaction mixture was allowed to warm to $\mathrm{rt}$ and stirred overnight. A steady stream of argon was then passed over the surface of the reaction mixture to remove the volatiles. Purified of the residue by bulb-to-bulb distillation gave enamine (1S,5R)-4 as a colorless, clear oil $(231 \mathrm{mg}$, 55\%): bp $182{ }^{\circ} \mathrm{C}, 0.45 \mathrm{~mm}$; IR (film) $\left(\mathrm{cm}^{-1}\right) 1697 \mathrm{~s}\left(\mathrm{C}=\mathrm{CNR}_{1} \mathrm{R}_{2}\right)$; ${ }^{1} \mathrm{H}$ NMR $\left(400 \mathrm{MHz}, \mathrm{CD}_{3} \mathrm{CN}\right) \delta 5.93(\mathrm{~d}, 1 \mathrm{H}, J=14 \mathrm{~Hz}, \mathrm{NCH}=\mathrm{CH})$, $4.32(\mathrm{dt}, 1 \mathrm{H}, J=14 \mathrm{~Hz}, J=7 \mathrm{~Hz}, \mathrm{NCH}=\mathrm{CH}), 3.80-3.82(\mathrm{~m}, 1 \mathrm{H}$, $\mathrm{NCH}), 2.17-1.96\left(\mathrm{~m}, 2 \mathrm{H}, \mathrm{CH}_{2}\right), 1.96-1.75\left(\mathrm{~m}, 3 \mathrm{H}, \mathrm{NCH}=\mathrm{CHCH}_{2}\right.$ and $\mathrm{CH}_{\mathrm{A}} \mathrm{CH}_{\mathrm{B}}$ ), 1.67-1.47 (m, $\left.4 \mathrm{H}, 2 \times \mathrm{CH}_{2}\right), 1.41-1.31(\mathrm{~m}, 6 \mathrm{H}, 3 \mathrm{x}$
$\left.\mathrm{CH}_{2}\right), 1.26\left(\mathrm{dd}, 1 \mathrm{H}, J=13 \mathrm{~Hz}, J=5.5 \mathrm{~Hz}, \mathrm{CH}_{\mathrm{A}} \mathrm{CH}_{\mathrm{B}}\right), 1.16(\mathrm{~s}, 3 \mathrm{H}$, $\left.\mathrm{CH}_{3}\right), 0.92\left(\mathrm{t}, 3 \mathrm{H}, J=8 \mathrm{~Hz}, \mathrm{CH}_{2} \mathrm{CH}_{3}\right) ;{ }^{13} \mathrm{C} \operatorname{NMR}(101 \mathrm{MHz}) \delta 129.5$ $(\mathrm{NCH}=\mathrm{CH}), 104.0(\mathrm{NCH}=\mathrm{CH}), 60.1\left(\mathrm{NC}\left(\mathrm{CH}_{3}\right)\right), 55.0(\mathrm{NCH})$, $36.4\left(\mathrm{CH}_{2}\right), 35.4\left(\mathrm{CH}_{2}\right), 33.7\left(\mathrm{CH}_{2}\right), 30.9\left(\mathrm{NCH}=\mathrm{CHCH}_{2}\right), 26.7$ $\left(\mathrm{CH}_{2}\right), 24.9\left(\mathrm{CH}_{3}\right), 22.2\left(\mathrm{CH}_{2}\right), 22.1\left(\mathrm{CH}_{2}\right), 18.9\left(\mathrm{CH}_{2}\right), 14.0$ $\left(\mathrm{CH}_{2} \mathrm{CH}_{3}\right)$; HRMS (ESI/TOF) $\mathrm{m} / z[\mathrm{M}+\mathrm{H}]^{+}$calcd for $\mathrm{C}_{14} \mathrm{H}_{26} \mathrm{~N}$ 208.2059; found 208.2060.

General Procedure for Enamine Alkylation. (R)-2-Ethylhexanal ((R)-3). Enamine (1S,5R)-4 (188 mg, $0.90 \mathrm{mmol}), \mathrm{CD}_{3} \mathrm{CN}$ $(1 \mathrm{~mL})$, and EtI $(281 \mathrm{mg}, 1.80 \mathrm{mmol})$ were placed in an NMR tube fitted with a PTFE valve. This mixture was heated at $65{ }^{\circ} \mathrm{C}$ for $16 \mathrm{~h}$ with occasional shaking until consumption of the enamine was complete by ${ }^{1} \mathrm{H}$ NMR spectroscopy. Buffer solution ( $\mathrm{AcOH}(0.5 \mathrm{~g})$, $\mathrm{NaOAc}(0.5 \mathrm{~g})$, and $\left.\mathrm{H}_{2} \mathrm{O}(1 \mathrm{~mL}) ; 0.5 \mathrm{~mL}\right)$ was then added and the mixture stirred at $\mathrm{rt}$ for $5 \mathrm{~min}$. The mixture was then partitioned between $\mathrm{Et}_{2} \mathrm{O}(20 \mathrm{~mL})$ and $\mathrm{H}_{2} \mathrm{O}(10 \mathrm{~mL})$. The organic layer was separated and the aq layer back-extracted with $\mathrm{Et}_{2} \mathrm{O}(2 \times 20 \mathrm{~mL})$. The combined organic layers were washed with brine $(20 \mathrm{~mL})$, dried $\left(\mathrm{MgSO}_{4}\right)$, and carefully reduced under vacuum $\left(152 \mathrm{~mm}, 0{ }^{\circ} \mathrm{C}\right)$. Purification of the residue by column chromatography $\left(\mathrm{SiO}_{2}, 5 \% \mathrm{Et}_{2} \mathrm{O}\right.$ in petroleum ether) gave $(R)$-aldehyde ${ }^{12}((R)-3)$ as a clear oil $(81: 19$ er, $\left.{ }^{1,21} 43 \mathrm{mg}, 38 \%\right): R_{f}=0.40\left(5 \% \mathrm{Et}_{2} \mathrm{O}\right.$ in petroleum ether $)$.

Trimethyltropane $(1 R, 5 R)-20$ Synthesis. (-)-(R)-2-Methyl- $N$ ((R)-4-methyl-1,4-bis (2-methyl-1,3-dioxolan-2-yl)pentan-3-yl)propane-2-sulfinamide $\left(\left(\boldsymbol{R}_{s^{\prime}}, \boldsymbol{R}\right)\right.$-15). 2-(2-Iodoethyl)-2-methyl-1,3-dioxolane $^{28 \mathrm{~b}}(5.56 \mathrm{~g}, 23.0 \mathrm{mmol})$ was dissolved in pentane $/ \mathrm{Et}_{2} \mathrm{O}(3: 2$, $225 \mathrm{~mL}$ ) at rt with stirring. The resulting solution was cooled to -78 ${ }^{\circ} \mathrm{C}$, and $t$-BuLi (1.7 $\mathrm{M}$ in pentane, $28.4 \mathrm{~mL}, 48.3 \mathrm{mmol}$ ) was added dropwise. The mixture was stirred at $-78{ }^{\circ} \mathrm{C}$ for $5 \mathrm{~min}$, then warmed to $\mathrm{rt}$, which resulted in formation of a white slurry. The mixture was stirred at $\mathrm{rt}$ for $1 \mathrm{~h}$, then recooled to $-78{ }^{\circ} \mathrm{C}$. The freshly prepared organolithium 14 was transferred, dropwise via cannula, to a solution of sulfinimine $(R)-13^{12}(2.40 \mathrm{~g}, 9.2 \mathrm{mmol}, 98: 2 \mathrm{er})$ in THF $(52 \mathrm{~mL})$ at $-78^{\circ} \mathrm{C}$. After $16 \mathrm{~h}$ at $-78^{\circ} \mathrm{C}$, the mixture was quenched with $\mathrm{MeOH}$ $(100 \mathrm{~mL})$, warmed to $\mathrm{rt}$, then diluted with $\mathrm{H}_{2} \mathrm{O}(400 \mathrm{~mL})$. The organic layer was separated, and the aq layer extracted with $\mathrm{Et}_{2} \mathrm{O}(4 \times$ $250 \mathrm{~mL})$. The combined organic layers were dried $\left(\mathrm{Na}_{2} \mathrm{SO}_{4}\right)$ and evaporated under reduced pressure. Purification of the residue by column chromatography $\left(\mathrm{SiO}_{2}\right.$, gradient elution $50-80 \%$ EtOAc in petroleum ether) gave bisketal sulfinamide $\left(\boldsymbol{R}_{S}, \boldsymbol{R}\right)-\mathbf{1 5}$ as a colorless, clear oil (90:10 dr as determined by integration of the ${ }^{1} \mathrm{H}$ NMR resonances at $\delta 3.21$ and 3.03, $3.08 \mathrm{~g}, 89 \%): R_{f}=0.12$ (80\% EtOAc in petroleum ether); $[\alpha]_{\mathrm{D}}^{25}-78.8\left(\mathrm{c} 0.3, \mathrm{CHCl}_{3}\right)$; IR (neat) $\left(\mathrm{cm}^{-1}\right) 3275$ $\mathrm{w}(\mathrm{N}-\mathrm{H}), 1059 \mathrm{~s}(\mathrm{~S}=\mathrm{O}$ and $\mathrm{O}-\mathrm{C}-\mathrm{O}) ;{ }^{1} \mathrm{H}$ NMR $(400 \mathrm{MHz}) \delta 5.30$ (br s, $1 \mathrm{H}, \mathrm{NH}), 4.06-3.90\left(\mathrm{~m}, 8 \mathrm{H}, 2 \times \mathrm{OC}_{2} \mathrm{H}_{4} \mathrm{O}\right), 3.29-3.27(\mathrm{~m}, 1 \mathrm{H}$, $\mathrm{NHCH}), 2.01-1.84\left(\mathrm{~m}, 2 \mathrm{H}, \mathrm{CHCH}_{2} \mathrm{CH}_{2}\right), 1.72-1.64(\mathrm{~m}, 1 \mathrm{H}$, $\left.\mathrm{CHCH}_{\mathrm{A}} \mathrm{H}_{\mathrm{B}}\right), 1.56-1.46\left(\mathrm{~m}, 1 \mathrm{H}, \mathrm{CHCH}_{\mathrm{A}} \mathrm{H}_{\mathrm{B}}\right), 1.34\left(\mathrm{~s}, 3 \mathrm{H}, \mathrm{CH}_{3}\right), 1.32$ $\left(\mathrm{s}, 3 \mathrm{H}, \mathrm{CH}_{3}\right), 1.23\left(\mathrm{~s}, 9 \mathrm{H}, \mathrm{C}\left(\mathrm{CH}_{3}\right)_{3}\right), 1.08\left(\mathrm{~s}, 3 \mathrm{H}, \mathrm{CH}_{3}\right), 0.96(\mathrm{~s}, 3 \mathrm{H}$, $\left.\mathrm{CH}_{3}\right) ;{ }^{13} \mathrm{C}$ NMR $(101 \mathrm{MHz}) \delta 114.6(\mathrm{O}-\mathrm{C}-\mathrm{O}), 110.0(\mathrm{O}-\mathrm{C}-\mathrm{O})$, $65.2\left(\mathrm{OCH}_{2}\right), 64.6\left(\mathrm{OCH}_{2}\right), 64.5\left(\mathrm{OCH}_{2}\right), 63.6\left(\mathrm{OCH}_{2}\right), 58.5$

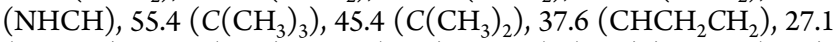
$\left(\mathrm{CHCH}_{2}\right), 23.7\left(\mathrm{CH}_{3}\right), 23.1\left(\mathrm{CH}_{3}\right), 22.9\left(\mathrm{C}\left(\mathrm{CH}_{3}\right)_{3}\right), 19.3\left(\mathrm{CH}_{3}\right)$, $16.8\left(\mathrm{CH}_{3}\right)$; HRMS (ESI/TOF) $\mathrm{m} / z[\mathrm{M}+\mathrm{H}]^{+}$calcd for $\mathrm{C}_{18} \mathrm{H}_{36} \mathrm{NO}_{5} \mathrm{~S}$ 378.2309; found 378.2300.

(-)-(1S,5R)-1,4,4-Trimethyl-8-azabicyclo[3.2.1]octan-3-one ((1S,5R)-16). $\mathrm{HCl}\left(2 \mathrm{M}\right.$ in $\left.\mathrm{Et}_{2} \mathrm{O}, 100 \mathrm{~mL}\right)$ was added to a stirred solution of bisketal sulfinamide $\left(\boldsymbol{R}_{\mathrm{S}}, \boldsymbol{R}\right)-\mathbf{1 5}(3.02 \mathrm{~g}, 8.0 \mathrm{mmol})$ in EtOH $(200 \mathrm{~mL})$ at $\mathrm{rt}$. The reaction mixture was then heated at $75^{\circ} \mathrm{C}$ for 3 days, then cooled to rt, and evaporated under reduced pressure. Aq $\mathrm{NaOH}(3 \mathrm{M}, 120 \mathrm{~mL})$ was added to the residue and the resulting suspension stirred for $15 \mathrm{~min}$, then washed with $\mathrm{CH}_{2} \mathrm{Cl}_{2}(5 \times 100$ $\mathrm{mL})$. The combined organic layers were dried $\left(\mathrm{Na}_{2} \mathrm{SO}_{4}\right)$ and concentrated under reduced pressure. Purification of the residue by column chromatography $\left(\mathrm{SiO}_{2}\right.$, gradient elution $0-25 \% \mathrm{MeOH}$ in EtOAc) gave tropinone (1S,5R)-16 as a white solid (896 mg, 67\%), recrystallization from $30 \% \mathrm{Et}_{2} \mathrm{O}$ in petroleum ether gave colorless crystals (682 mg, 51\%): $\mathrm{mp} 35-37{ }^{\circ} \mathrm{C}, R_{f}=0.16(10 \% \mathrm{MeOH}$ in EtOAc); $[\alpha]_{\mathrm{D}}^{25}-56.5$ ( c $\left.0.5, \mathrm{CHCl}_{3}\right)$; IR (neat) $\left(\mathrm{cm}^{-1}\right) 3302 \mathrm{w}(\mathrm{N}-$ $\mathrm{H}), 1703 \mathrm{~s}(\mathrm{C}=\mathrm{O}) ;{ }^{1} \mathrm{H}$ NMR $(400 \mathrm{MHz}) \delta 3.21(\mathrm{~d}, 1 \mathrm{H}, \mathrm{NCH}), 2.53$ $\left(\mathrm{dd}, 1 \mathrm{H}, J=15.5 \mathrm{~Hz}, J=2.5 \mathrm{~Hz}, \mathrm{CH}_{\mathrm{A}} \mathrm{H}_{\mathrm{B}} \mathrm{C}=\mathrm{O}\right), 2.26($ br s, $1 \mathrm{H}, \mathrm{NH})$, 
$2.16\left(\mathrm{~d}, 1 \mathrm{H}, J=15.5 \mathrm{~Hz}, \mathrm{CH}_{\mathrm{A}} \mathrm{H}_{\mathrm{B}} \mathrm{C}=\mathrm{O}\right), 1.90-1.73(\mathrm{~m}, 2 \mathrm{H}$, $\left.\mathrm{CHCH}_{2}\right), 1.65-1.58\left(\mathrm{~m}, 1 \mathrm{H}, \mathrm{CHCH}_{2} \mathrm{CH}_{\mathrm{A}} \mathrm{H}_{\mathrm{B}}\right), 1.46(\mathrm{tq}, 1 \mathrm{H}, J=13$ $\left.\mathrm{Hz}, J=3 \mathrm{~Hz}, \mathrm{CHCH}_{2} \mathrm{CH}_{\mathrm{A}} \mathrm{H}_{\mathrm{B}}\right), 1.34\left(\mathrm{~s}, 3 \mathrm{H}, \mathrm{CH}_{3}\right), 1.24\left(\mathrm{~s}, 3 \mathrm{H}, \mathrm{CH}_{3}\right)$, $1.03\left(\mathrm{~s}, 3 \mathrm{H}, \mathrm{CH}_{3}\right) ;{ }^{13} \mathrm{C}$ NMR $(101 \mathrm{MHz}) \delta 214.2(\mathrm{C}=\mathrm{O}), 65.9$ $(\mathrm{NCH}), 62.0\left(\mathrm{NCCH}_{3}\right), 53.0\left(\mathrm{CH}_{2} \mathrm{C}=\mathrm{O}\right), 49.7\left(\mathrm{C}\left(\mathrm{CH}_{3}\right)_{2}\right), 36.0$ $\left(\mathrm{CHCH}_{2} \mathrm{CH}_{2}\right), 27.3\left(\mathrm{CHCH}_{2}\right), 26.3\left(\mathrm{CH}_{3}\right), 25.7\left(\mathrm{CH}_{3}\right), 20.9\left(\mathrm{CH}_{3}\right)$; HRMS (ESI/TOF) $\mathrm{m} / z[\mathrm{M}+\mathrm{H}]^{+}$calcd for $\mathrm{C}_{10} \mathrm{H}_{18} \mathrm{NO}$ 168.1383; found 168.1378 .

(-)-(1S,3R/S,5R)-1,4,4-Trimethyl-8-azabicyclo[3.2.1]octan-3-ol $((1 S, 3 R / S, 5 R)-17)$. LAH $(150 \mathrm{mg}, 4.0 \mathrm{mmol})$ was dissolved in THF (8 $\mathrm{mL})$ with stirring and external cooling (ice-bath). Then tropinone $(1 S, 5 R)-16(600 \mathrm{mg}, 3.59 \mathrm{mmol})$ in THF $(9 \mathrm{~mL})$ was added, dropwise, with stirring at $0{ }^{\circ} \mathrm{C}$. The reaction mixture was maintained at $0{ }^{\circ} \mathrm{C}$ for $30 \mathrm{~min}$, then warmed to $\mathrm{rt}$ and stirred overnight. After this time, the mixture was recooled to $0{ }^{\circ} \mathrm{C}$ and then quenched with $\mathrm{H}_{2} \mathrm{O}$ $(180 \mu \mathrm{L})$, then $15 \%$ aq $\mathrm{NaOH}(180 \mu \mathrm{L})$, then $\mathrm{H}_{2} \mathrm{O}(500 \mu \mathrm{L})$. [Care! Add slowly!] The resulting suspension was filtered, and the filter cake washed with $\mathrm{CH}_{2} \mathrm{Cl}_{2}(4 \times 20 \mathrm{~mL})$. The filtrate was concentrated under reduced pressure, to give an inseparable mixture of diastereomers of tropinol $(\mathbf{1 S}, \mathbf{3 R} / \mathrm{S}, \mathbf{5 R})-\mathbf{1 7}$ as a clear colorless oil (57:43 $\mathrm{dr}$ as determined by integration of the ${ }^{1} \mathrm{H}$ NMR resonances at $\delta 2.85$ and 2.92, $590 \mathrm{mg}, 97 \%): R_{f}=0.07(20 \% \mathrm{MeOH}$ in EtOAc); $[\alpha]_{\mathrm{D}}^{25}-20.8\left(\mathrm{c} 0.2, \mathrm{CHCl}_{3}\right)$; IR (neat) $\left(\mathrm{cm}^{-1}\right) 3164 \mathrm{brm}(\mathrm{N}-\mathrm{H}$ and $\mathrm{O}-\mathrm{H}) ;{ }^{1} \mathrm{H}$ NMR (400 MHz) $\delta 3.52-3.47$ (m 2H, 2 x CHOH), 2.92 and $2.85(\mathrm{~d}, 2 \mathrm{H}, J=7 \mathrm{~Hz}, 2 \times \mathrm{NCH}), 2.27-2.21(\mathrm{~m}, 1 \mathrm{H}$, $\left.\mathrm{NCHCH}_{\mathrm{A}} \mathrm{H}_{\mathrm{B}}\right), 2.04-1.97\left(\mathrm{~m}, 1 \mathrm{H}, \mathrm{CHCH}_{2} \mathrm{CH}_{\mathrm{A}} \mathrm{H}_{\mathrm{B}}\right), 1.82-1.25(14 \mathrm{H}$, $\mathrm{NCHCH}_{\mathrm{A}} \mathrm{H}_{\mathrm{B}}, \mathrm{CHCH}_{2} \mathrm{CH}_{\mathrm{A}} \mathrm{H}_{\mathrm{B}}, \mathrm{NCHCH}_{2}, \mathrm{CHCH}_{2} \mathrm{CH}_{2}, 2 \times \mathrm{OH}, 2 \times$ $\mathrm{NH}$ and $\left.2 \times \mathrm{CH}_{2} \mathrm{CHOH}\right), 1.20\left(\mathrm{~s}, 3 \mathrm{H}, \mathrm{CH}_{3}\right), 1.17\left(\mathrm{~s}, 3 \mathrm{H}, \mathrm{CH}_{3}\right), 0.97$ $\left(\mathrm{s}, 6 \mathrm{H}, 2 \times \mathrm{CH}_{3}\right), 0.94\left(\mathrm{~s}, 3 \mathrm{H}, \mathrm{CH}_{3}\right), 0.91\left(\mathrm{~s}, 3 \mathrm{H}, \mathrm{CH}_{3}\right) ;{ }^{13} \mathrm{C} \mathrm{NMR}$ $(101 \mathrm{MHz}) \delta 73.7(\mathrm{CHOH}), 71.8(\mathrm{CHOH}), 65.9(\mathrm{NCH}), 64.8$ $(\mathrm{NCH}), 59.4\left(\mathrm{NC}\left(\mathrm{CH}_{3}\right)\right), 58.0\left(\mathrm{NC}\left(\mathrm{CH}_{3}\right)\right), 45.2\left(\mathrm{CH}_{2} \mathrm{CHOH}\right), 43.5$ $\left(\mathrm{CH}_{2} \mathrm{CHOH}\right), 38.3\left(\mathrm{C}\left(\mathrm{CH}_{3}\right)_{2}\right), 37.1\left(\mathrm{C}\left(\mathrm{CH}_{3}\right)_{2}\right), 35.4\left(\mathrm{CHCH}_{2} \mathrm{CH}_{2}\right)$, $35.3\left(\mathrm{CHCH}_{2} \mathrm{CH}_{2}\right), 27.4\left(\mathrm{CH}_{3}\right), 27.3\left(\mathrm{CH}_{3}\right), 27.3\left(\mathrm{NCHCH}_{2}\right), 26.7$ $\left(\mathrm{CH}_{3}\right), 26.5\left(\mathrm{NCHCH}_{2}\right), 24.2\left(\mathrm{CH}_{3}\right), 23.0\left(\mathrm{CH}_{3}\right), 19.1\left(\mathrm{CH}_{3}\right)$; HRMS (ESI/TOF) $\mathrm{m} / z[\mathrm{M}+\mathrm{H}]^{+}$calcd for $\mathrm{C}_{10} \mathrm{H}_{19} \mathrm{NO}$ 170.1539; found 170.1533 .

(-)-(1S,3R/S,5R)-Methyl 1,4,4-trimethyl-3-(((methylthio)carbonothioyl)oxy)-8-aza-bicyclo[3.2.1]octane-8-carbodithioate ((1S,3R/S,5R)-18). Tropinol (1S,3R/S,5R)-17 (460 mg, $2.72 \mathrm{mmol})$ was dissolved in THF $(10 \mathrm{~mL})$, with stirring at rt. Imidazole $(41 \mathrm{mg}$, $0.60 \mathrm{mmol})$ and $\mathrm{NaH}(60 \%$ dispersion, $570 \mathrm{mg}, 14.25 \mathrm{mmol})$ were added, and the resulting mixture stirred at $\mathrm{rt}$ for $30 \mathrm{~min} . \mathrm{CS}_{2}(828 \mu \mathrm{L}$, $13.8 \mathrm{mmol}$ ) was added, dropwise, resulting in an orange coloration. The mixture was heated at $70{ }^{\circ} \mathrm{C}$ for $16 \mathrm{~h}$, then cooled to rt and MeI $(340 \mu \mathrm{L}, 5.46 \mathrm{mmol})$ added, dropwise. The resulting mixture was stirred at $\mathrm{rt}$ for $16 \mathrm{~h}$, then cooled to $0{ }^{\circ} \mathrm{C}$ and quenched with brine $(20$ $\mathrm{mL})$. After warming to rt, the mixture was diluted with $\mathrm{H}_{2} \mathrm{O}(30 \mathrm{~mL})$ and extracted with $\mathrm{CH}_{2} \mathrm{Cl}_{2}(4 \times 50 \mathrm{~mL})$. The combined organic layers were dried $\left(\mathrm{Na}_{2} \mathrm{SO}_{4}\right)$ and evaporated under reduced pressure. Purification of the residue by column chromatography $\left(\mathrm{SiO}_{2}\right.$, gradient elution $0-10 \%$ EtOAc in petroleum ether) gave an inseparable mixture of xanthate diastereomers $(1 S, 3 R / S, 5 R)-18$ as an orange oil (60:40 $\mathrm{dr}$ as determined by integration of the ${ }^{1} \mathrm{H}$ NMR resonances at $\delta 5.12$ and $5.19,715 \mathrm{mg}, 75 \%): R_{f}=0.77(10 \% \mathrm{EtOAc}$ in petroleum ether); $[\alpha]_{\mathrm{D}}^{25}-33.8\left(c 0.2, \mathrm{CHCl}_{3}\right)$; IR (neat) $\left(\mathrm{cm}^{-1}\right) 1215 \mathrm{~s}(\mathrm{C}=\mathrm{S})$, $1056 \mathrm{~s}(\mathrm{MeS}-\mathrm{CS}-\mathrm{O}-\mathrm{R}) ;{ }^{1} \mathrm{H} \mathrm{NMR}(400 \mathrm{MHz}) \delta 5.77$ (dd, 1H, $J=$ $\left.11 \mathrm{~Hz}, J=6 \mathrm{~Hz}, \mathrm{CHOCS}_{2} \mathrm{CH}_{3}\right), 5.51(\mathrm{~d}, 1 \mathrm{H}, J=4.5 \mathrm{~Hz}$, $\mathrm{CHOCS}_{2} \mathrm{CH}_{3} \mathrm{Me}$ ), 5.19 (d, $\left.1 \mathrm{H}, J=6 \mathrm{~Hz}, \mathrm{NCH}\right), 5.12(\mathrm{~d}, 1 \mathrm{H}, J=7$ $\mathrm{Hz}, \mathrm{NCH}$ ), 2.65-2.61 (m, 2H, $\left.2 \times \mathrm{CH}_{\mathrm{A}} \mathrm{H}_{\mathrm{B}} \mathrm{CHOH}\right), 2.59(\mathrm{~s}, 3 \mathrm{H}$, $\left.\mathrm{OCS}_{2} \mathrm{CH}_{3}\right), 2.58\left(\mathrm{~s}, 6 \mathrm{H}, 2 \times \mathrm{NCS}_{2} \mathrm{CH}_{3}\right), 2.52\left(\mathrm{~s}, 3 \mathrm{H}, \mathrm{OCS}_{2} \mathrm{CH}_{3}\right)$, 2.28-2.21 (m, $\left.2 \mathrm{H}, \mathrm{CH}_{\mathrm{A}} \mathrm{H}_{\mathrm{B}}\right), 2.18-2.11\left(\mathrm{~m}, 2 \mathrm{H}, \mathrm{CH}_{\mathrm{A}} \mathrm{H}_{\mathrm{B}}\right), 2.04-1.80$ $\left(6 \mathrm{H}, 6 \times \mathrm{CH}_{\mathrm{A}} \mathrm{H}_{\mathrm{B}}\right), 1.86\left(\mathrm{~s}, 3 \mathrm{H}, \mathrm{CH}_{3}\right), 1.83\left(\mathrm{~s}, 3 \mathrm{H}, \mathrm{CH}_{3}\right), 1.17(\mathrm{~s}, 3 \mathrm{H}$, $\left.\mathrm{CH}_{3}\right), 1.17\left(\mathrm{~s}, 3 \mathrm{H}, \mathrm{CH}_{3}\right), 1.02\left(\mathrm{~s}, 3 \mathrm{H}, \mathrm{CH}_{3}\right), 1.00\left(\mathrm{~s}, 3 \mathrm{H}, \mathrm{CH}_{3}\right) ;{ }^{13} \mathrm{C}$ NMR $(101 \mathrm{MHz}) \delta 215.8(\mathrm{O}(\mathrm{C}=\mathrm{S}) \mathrm{SMe}), 215.2(\mathrm{O}(\mathrm{C}=\mathrm{S}) \mathrm{SMe})$, $196.4(\mathrm{~N}(C=S) \mathrm{SMe}), 195.7(\mathrm{~N}(C=S) \mathrm{SMe}), 84.7\left(\mathrm{COCS}_{2} \mathrm{Me}\right), 82.6$ $\left(\mathrm{COCS}_{2} \mathrm{Me}\right), 71.9(\mathrm{NCH}), 71.4(\mathrm{NCH}), 68.1\left(\mathrm{NC}\left(\mathrm{CH}_{3}\right), 67.0\right.$ $\left(\mathrm{NC}\left(\mathrm{CH}_{3}\right)\right), 43.3\left(\mathrm{C}\left(\mathrm{CH}_{3}\right)_{2}\right), 43.2\left(\mathrm{C}_{2}\left(\mathrm{CH}_{3}\right)_{2}\right), 38.5\left(\mathrm{CH}_{2}\right), 38.3$ $\left(\mathrm{CH}_{2}\right), 38.1\left(\mathrm{CH}_{2}\right), 37.8\left(\mathrm{CH}_{2}\right), 26.9\left(\mathrm{CH}_{3}\right), 26.7\left(\mathrm{CH}_{3}\right), 25.3\left(\mathrm{CH}_{3}\right)$, $23.8\left(\mathrm{CH}_{3}\right), 22.4\left(\mathrm{CH}_{3}\right), 21.8\left(\mathrm{CHCH}_{2} \mathrm{CH}_{2}\right), 21.5\left(\mathrm{CHCH}_{2} \mathrm{CH}_{2}\right)$, $19.6\left(\mathrm{CH}_{3}\right), 19.6\left(\mathrm{SCH}_{3}\right), 19.5\left(\mathrm{SCH}_{3}\right), 19.0\left(\mathrm{SCH}_{3}\right), 18.7\left(\mathrm{SCH}_{3}\right)$;
HRMS (ESI/TOF) $m / z[\mathrm{M}+\mathrm{H}]^{+}$calcd for $\mathrm{C}_{14} \mathrm{H}_{24} \mathrm{ONS}_{4}$ 350.0735; found 350.0734 .

(-)-(1R,5R)-Methyl 1,4,4-trimethyl-8-azabicyclo[3.2.1]octane-8carbodithioate ((1R,5R)-19). Xanthate $(1 S, 3 R / S, 5 R)-18(100 \mathrm{mg}$, $0.286 \mathrm{mmol})$ and AIBN $(28 \mathrm{mg}, 0.17 \mathrm{mmol})$ were dried under vacuum $(0.1 \mathrm{mmHg})$ for $1 \mathrm{~h}$. Benzene (degassed under $\mathrm{N}_{2}$ for $1 \mathrm{~h}, 2.5 \mathrm{~mL}$ ) was added, followed by $\mathrm{Bu}_{3} \mathrm{SnH}(155 \mu \mathrm{L}, 0.58 \mathrm{mmol})$, dropwise with stirring at rt. The mixture was heated at $85{ }^{\circ} \mathrm{C}$ for $16 \mathrm{~h}$, then cooled to rt and the volatiles removed by evaporation under reduced pressure. Purification of the residue by column chromatography $\left(\mathrm{SiO}_{2}\right.$, gradient elution $0-2 \% \mathrm{Et}_{2} \mathrm{O}$ in petroleum ether) gave carbodithioate $(1 R, 5 R)$ 19 as a yellow oil $(50 \mathrm{mg}, 72 \%): R_{f}=0.45\left(2 \% \mathrm{Et}_{2} \mathrm{O}\right.$ in petroleum ether); $[\alpha]_{\mathrm{D}}^{25}-183.3\left(\right.$ ( $\left.0.3, \mathrm{CHCl}_{3}\right) ;{ }^{1} \mathrm{H}$ NMR $(400 \mathrm{MHz}) \delta 5.05(\mathrm{br}$ $\mathrm{s}, 1 \mathrm{H}, \mathrm{NCH}), 2.60\left(\mathrm{~s}, 3 \mathrm{H}, \mathrm{SCH}_{3}\right), 2.30-2.23(\mathrm{~m}, 1 \mathrm{H}$, $\mathrm{NCHCH}_{\mathrm{A}} \mathrm{CH}_{\mathrm{B}}$ ), 1.91-1.80 (m, 4H, $\mathrm{CH}_{2} \mathrm{CH}_{2}, \mathrm{CH}_{2} \mathrm{CH}_{2}$ ), 1.85 (s, $\left.3 \mathrm{H}, \mathrm{CH}_{3}\right), 1.64-1.56\left(\mathrm{~m}, 1 \mathrm{H}, \mathrm{CHCH}_{2} \mathrm{CH}_{\mathrm{A}} \mathrm{CH}_{\mathrm{B}}\right), 1.33-1.23(\mathrm{~m}, 2 \mathrm{H}$, $\left.\mathrm{NCHCH}_{\mathrm{A}} \mathrm{CH}_{\mathrm{B}}, \mathrm{CHCH}_{2} \mathrm{CH}_{\mathrm{A}} \mathrm{CH}_{\mathrm{B}}\right), 1.08\left(\mathrm{~s}, 3 \mathrm{H}, \mathrm{CH}_{3}\right), 0.93(\mathrm{~s}, 3 \mathrm{H}$, $\left.\mathrm{CH}_{3}\right) ;{ }^{13} \mathrm{C}$ NMR $(101 \mathrm{MHz}) \delta 194.8(\mathrm{C}=\mathrm{S}), 72.9(\mathrm{NCH}), 68.9$ $\left(\mathrm{NC}\left(\mathrm{CH}_{3}\right)\right), 39.1\left(\mathrm{C}\left(\mathrm{CH}_{3}\right)_{2}\right), 38.0\left(\mathrm{CH}_{2} \mathrm{CH}_{2}\right), 34.3\left(\mathrm{NCHCH}_{2}\right), 32.4$ $\left(\mathrm{CHCH}_{2} \mathrm{CH}_{2}\right), 27.6\left(\mathrm{CH}_{3}\right), 27.2\left(\mathrm{CH}_{3}\right), 24.6\left(\mathrm{CH}_{3}\right), 21.9\left(\mathrm{CH}_{2} \mathrm{CH}_{2}\right)$, $19.5\left(\mathrm{SCH}_{3}\right) ; \operatorname{HRMS}(\mathrm{ESI} / \mathrm{TOF}) \mathrm{m} / z[\mathrm{M}+\mathrm{Na}]^{+}$calcd for $\mathrm{C}_{12} \mathrm{H}_{21} \mathrm{NNaS}_{2}$ 266.1008; found 266.1006.

(-)-(1R,5R)-1,4,4-Trimethyl-8-azabicyclo[3.2.1]octane ((1R,5R)20). Aq $\mathrm{HCl}(6 \mathrm{M}, 10 \mathrm{~mL})$ was added to a stirred solution of carbodithioate $(1 R, 5 R)-19(100 \mathrm{mg}, 0.41 \mathrm{mmol})$ at rt. The resulting mixture was heated at $130{ }^{\circ} \mathrm{C}$ for 3 days. After this time, the mixture was cooled to rt, basified with $3 \mathrm{M}$ aq $\mathrm{NaOH}(30 \mathrm{~mL})$, and the resulting suspension extracted with $\mathrm{Et}_{2} \mathrm{O}(3 \times 50 \mathrm{~mL})$. The combined organic layers were dried $\left(\mathrm{Na}_{2} \mathrm{SO}_{4}\right)$, and the mixture concentrated by careful evaporation $\left(228 \mathrm{~mm}, 35^{\circ} \mathrm{C}\right)$ to give tropane $(1 R, 5 R)-20$ as a clear oil (53 mg, 84\%): $[\alpha]_{\mathrm{D}}^{25}-76.1\left(c 0.3, \mathrm{CHCl}_{3}\right) ;{ }^{1} \mathrm{H}$ NMR $(400$ $\mathrm{MHz}) \delta 2.82(\mathrm{~d}, 1 \mathrm{H}, J=6.5 \mathrm{~Hz}, \mathrm{NHCH}), 1.84-1.68(\mathrm{~m}, 1 \mathrm{H}$, $\left.\mathrm{NHCHCH}_{\mathrm{A}} \mathrm{CH}_{\mathrm{B}}\right), 1.56-1.18\left(\mathrm{~m}, 7 \mathrm{H}, 3 \times \mathrm{CH}_{2}, \mathrm{NHCHCH}_{\mathrm{A}} \mathrm{CH}_{\mathrm{B}}\right)$, $1.15\left(\mathrm{~s}, 3 \mathrm{H}, \mathrm{CH}_{3}\right), 1.00\left(\mathrm{~s}, 3 \mathrm{H}, \mathrm{CH}_{3}\right), 0.80\left(\mathrm{~s}, 3 \mathrm{H}, \mathrm{CH}_{3}\right) ;{ }^{13} \mathrm{C} \mathrm{NMR}$ $(101 \mathrm{MHz}) \delta 65.8(\mathrm{NCH}), 58.6\left(\mathrm{NC}\left(\mathrm{CH}_{3}\right)\right), 36.0\left(\mathrm{CH}_{2} \mathrm{CH}_{2}\right), 34.8$

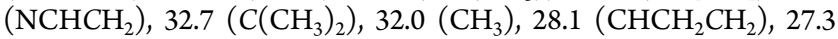
$\left(\mathrm{CH}_{3}\right), 27.1\left(\mathrm{CH}_{3}\right), 25.3\left(\mathrm{CH}_{2} \mathrm{CH}_{2}\right)$; HRMS (ESI/TOF) $\mathrm{m} / z[\mathrm{M}$ $+\mathrm{H}]^{+}$calcd for $\mathrm{C}_{10} \mathrm{H}_{20} \mathrm{~N}$ 154.1590; found 154.1598.

(-)-(1R,5R)-1,4,4-Trimethyl-8-azabicyclo[3.2.1]octane-8-carbaldehyde $((1 R, 5 R)-21)$. According to the general procedure for formamide synthesis, reaction of tropane $(1 R, 5 R)-20(356 \mathrm{mg}, 2.32$ $\mathrm{mmol}), \mathrm{BnEt}_{3} \mathrm{NCl}(262 \mathrm{mg}, 1.15 \mathrm{mmol}), \mathrm{CHCl}_{3}(1.87 \mathrm{~mL}, 23.40$ $\mathrm{mmol})$, and $12.5 \mathrm{M}$ aq $\mathrm{NaOH}(6.40 \mathrm{~mL})$ in $\mathrm{CH}_{2} \mathrm{Cl}_{2}(10.0 \mathrm{~mL})$ at reflux for $16 \mathrm{~h}$ gave formamide $(\mathbf{1 R , 5 R})-\mathbf{2 1}$ as colorless crystals (400 $\mathrm{mg}, 95 \%$ ): $\mathrm{mp} 47-49{ }^{\circ} \mathrm{C}$; $[\alpha]_{\mathrm{D}}^{25}-1.2\left(\mathrm{c} 1.0, \mathrm{CHCl}_{3}\right)$; IR (neat) $\left(\mathrm{cm}^{-1}\right) 1650 \mathrm{~s}(\mathrm{C}=\mathrm{O}) ;{ }^{1} \mathrm{H}$ NMR $(400 \mathrm{MHz}) \delta 8.17(\mathrm{~s}, 1 \mathrm{H}, \mathrm{CHO})$, $4.23(\mathrm{~d}, 1 \mathrm{H}, J=7 \mathrm{~Hz}, \mathrm{NCH}), 1.85-1.42\left(\mathrm{~m}, 7 \mathrm{H}, \mathrm{CH}_{\mathrm{A}} \mathrm{H}_{\mathrm{B}}, 3 \times \mathrm{CH}_{2}\right)$, $1.44\left(\mathrm{~s}, 3 \mathrm{H}, \mathrm{NC}\left(\mathrm{CH}_{3}\right)\right), 1.27-1.22\left(\mathrm{~m}, 1 \mathrm{H}, \mathrm{CH}_{\mathrm{A}} \mathrm{H}_{\mathrm{B}}\right), 0.97(\mathrm{~s}, 3 \mathrm{H}$, $\left.\mathrm{CH}_{3}\right), 0.92\left(\mathrm{~s}, 3 \mathrm{H}, \mathrm{CH}_{3}\right) ;{ }^{13} \mathrm{C} \mathrm{NMR}(101 \mathrm{MHz}) \delta 156.4(\mathrm{C}=\mathrm{O}), 60.2$ $(\mathrm{NCH}), 60.0\left(\mathrm{NC}\left(\mathrm{CH}_{3}\right)\right), 37.4\left(\mathrm{CH}_{2}\right), 35.4\left(\mathrm{CH}_{2}\right), 35.0\left(\mathrm{C}\left(\mathrm{CH}_{3}\right)_{2}\right)$, 31.7 $\left(\mathrm{CH}_{2}\right), 27.0\left(\mathrm{CH}_{3}\right), 24.5\left(\mathrm{CH}_{3}\right), 23.7\left(\mathrm{CH}_{2}\right), 23.0\left(\mathrm{CH}_{3}\right)$; HRMS (ESI/TOF) $m / z[\mathrm{M}+\mathrm{H}]^{+}$calcd for $\mathrm{C}_{11} \mathrm{H}_{20} \mathrm{NO} 182.1539$; found 182.1541 .

(1R,5R)-8-((E)-Hex-1-en-1-yl)-1,4,4-trimethyl-8-azabicyclo[3.2.1]octane $((1 R, 5 R)-5)$. According to the general procedure for enamine synthesis, reaction of formamide $(1 R, 5 R)-21(426 \mathrm{mg}, 2.35 \mathrm{mmol})$ with pentylmagnesium chloride $(2.0 \mathrm{M}$ in THF, $1.5 \mathrm{~mL}, 2.93 \mathrm{mmol})$ in $\mathrm{Et}_{2} \mathrm{O}(2.5 \mathrm{~mL})$ at $\mathrm{rt}$ for $16 \mathrm{~h}$ gave, after distillation, enamine $(1 R, 5 R)-5$ as a colorless, clear oil $(525 \mathrm{mg}, 95 \%)$ : bp $175{ }^{\circ} \mathrm{C}(0.4$ $\mathrm{mm})$; IR (neat) $\left(\mathrm{cm}^{-1}\right) 1645 \mathrm{~s}\left(\mathrm{C}=\mathrm{CNR}_{1} \mathrm{R}_{2}\right) ;{ }^{1} \mathrm{H}$ NMR $(400 \mathrm{MHz}$, $\left.\mathrm{C}_{6} \mathrm{D}_{6}\right) \delta 6.23(\mathrm{~d}, 1 \mathrm{H}, J=14 \mathrm{~Hz}, \mathrm{NCH}=\mathrm{CH}), 4.51(\mathrm{dt}, 1 \mathrm{H}, J=14 \mathrm{~Hz}$, $J=7 \mathrm{~Hz}, \mathrm{NCH}=\mathrm{CH}), 3.36(\mathrm{~d}, J=7 \mathrm{~Hz}, 1 \mathrm{H}, \mathrm{NCH}), 2.16-2.12(\mathrm{~m}$, $\left.2 \mathrm{H}, \mathrm{NCH}=\mathrm{CHCH}_{2}\right), 1.79-1.01\left(\mathrm{~m}, 12 \mathrm{H}, 6 \times \mathrm{CH}_{2}\right), 1.15(\mathrm{~s}, 3 \mathrm{H}$, $\left.\mathrm{CH}_{3}\right), 1.13\left(\mathrm{~s}, 3 \mathrm{H}, \mathrm{CH}_{3}\right), 0.95\left(\mathrm{t}, 3 \mathrm{H}, J=7 \mathrm{~Hz}, \mathrm{CH}_{2} \mathrm{CH}_{3}\right), 0.80(\mathrm{~s}, 3 \mathrm{H}$, $\left.\mathrm{CH}_{3}\right) ;{ }^{13} \mathrm{C}$ NMR $\left(101 \mathrm{MHz}, \mathrm{C}_{6} \mathrm{D}_{6}\right) \delta 133.9(\mathrm{NCH}=\mathrm{CH}), 98.6$ $(\mathrm{NCH}=\mathrm{CH}), 65.9\left(\mathrm{NC}\left(\mathrm{CH}_{3}\right)\right), 62.4(\mathrm{NCH}), 37.7\left(\mathrm{CH}_{2}\right), 35.7$ $\left.\left(\mathrm{CH}_{2}\right), 35.3\left(\mathrm{C}_{2} \mathrm{CH}_{3}\right)_{2}\right), 34.8\left(\mathrm{CH}_{2}\right), 33.0\left(\mathrm{NCH}=\mathrm{CHCH}_{2}\right), 31.6$ $\left(\mathrm{CH}_{3}\right), 28.6\left(\mathrm{CH}_{2}\right), 26.4\left(\mathrm{CH}_{2}\right), 24.4\left(\mathrm{CH}_{3}\right), 24.1\left(\mathrm{CH}_{2}\right), 23.0\left(\mathrm{CH}_{2}\right)$, $14.7\left(\mathrm{CH}_{2} \mathrm{CH}_{3}\right)$; HRMS (ESI/TOF) $\mathrm{m} / z[\mathrm{M}+\mathrm{H}]^{+}$calcd for $\mathrm{C}_{16} \mathrm{H}_{30} \mathrm{~N}$ 236.2373; found 236.2371 . 
Asymmetric Alkylation of Enamine (1R,5R)-5 with Etl. (S)-2Ethylhexanal ((S)-3). According to the general procedure for enamine alkylation, reaction of enamine $(1 R, 5 R)-5(235 \mathrm{mg}, 1.0 \mathrm{mmol})$ with EtI $(312 \mathrm{mg}, 2.0 \mathrm{mmol})$ in $\mathrm{CD}_{3} \mathrm{CN}(1 \mathrm{~mL})$ at $65^{\circ} \mathrm{C}$ for $16 \mathrm{~h}$ gave, following hydrolysis with acidic buffer $(0.5 \mathrm{~mL})$ at rt for $5 \mathrm{~min}$, aldehyde $(S)-3^{12}$ as a clear oil (95:5 er, $\left.{ }^{12,23} 90 \mathrm{mg}, 63 \%\right)$.

Computational Methodology. Density functional theory (DFT) calculations were performed using the Gaussian 09 package. ${ }^{31}$ Optimizations of the enamine ground state structures and of transition state structures for alkylation were performed using the default (fine) grid density for numerical integration with the B3LYP, wB97XD, and M06-2X functionals. ${ }^{32}$ Optimizations were also performed with an atom-pairwise density independent Becke-Johnson damped D3dispersion correction $\left(s_{6}=1.0 ; a_{1}=0.3981 ; s_{8}=1.9889 ; a_{2}\right.$ 4.4211). ${ }^{33}$ Harmonic vibrational frequencies were computed for all optimized structures to verify that they were either minima or transition states, possessing zero imaginary frequencies and one imaginary frequency, respectively. The Pople 6-31G(d) basis set was used for all elements except I, which was described with the LANL2DZ effective core potential and associated valence basis of Hay and Wadt. ${ }^{34}$ Effects of solvation due to acetonitrile $(\varepsilon=35.688)$ were implicitly included in all geometry optimizations and in the evaluation of energies using a conductor-like polarizable continuum model (CPCM).$^{33}$ Gibbs energies were evaluated at the reaction temperature of $65{ }^{\circ} \mathrm{C}$. A quasi-rigid rotor harmonic oscillator approximation was applied, switching to a free rotor description of vibrational entropy below $100 \mathrm{~cm}^{-1}$. This mitigates spuriously large entropic terms from low frequencies, reducing the sensitivity of the computed selectivities to the choice of numerical convergence criteria or grid size. ${ }^{36}$ Conformers of the diastereomeric transition structures arising from rotation about the incipient $\mathrm{C}-\mathrm{C}$ bond were systematically generated and optimized for each enamine: in each case there are three TS geometries for attack from either enamine diastereoface. Stereoselectivities were computed from a summation of competing Boltzmann populations. ${ }^{37}$ Noncovalent interaction (NCI) isosurfaces were generated from the B3LYP densities using NCIplot using default density (0.2) and reduced density gradient (1.0) cutoffs. ${ }^{38}$ Molecular graphics were produced by Pymol, including Bondi Atomic van der Waals radii where appropriate. ${ }^{39}$

\section{ASSOCIATED CONTENT}

\section{S Supporting Information}

The Supporting Information is available free of charge on the ACS Publications website at DOI: 10.1021/acs.joc.7b01954.

${ }^{1} \mathrm{H}$ and ${ }^{13} \mathrm{C}$ NMR spectra, ${ }^{77} \mathrm{Se}$ NMR spectra for determination of er, and HPLC traces of formamides showing enantiopurity (PDF)

Determination of absolute configuration, Cartesian coordinates, imaginary frequencies, and computed energies (ZIP)

X-ray crystallographic data for compound $(S, 1 S, 1 R, 5 S)$ 11·THF (CIF)

\section{AUTHOR INFORMATION}

\section{Corresponding Authors}

*E-mail: robert.paton@chem.ox.ac.uk.

*E-mail: david.hodgson@chem.ox.ac.uk.

\section{ORCID $\odot$}

Robert S. Paton: 0000-0002-0104-4166

David. M. Hodgson: 0000-0001-7201-9841

\section{Notes}

The authors declare no competing financial interest.

\section{ACKNOWLEDGMENTS}

We thank the China Scholarship Council for a postdoctoral scholarship (to Y.L.), the EPSRC for a Studentship (to K.E.J.), the EPSRC and GlaxoSmithKline for an Organic Synthesis Studentship (to A.C.), the Higher Education Commission of Pakistan for an IRSIP scholarship (to A.K.), and the European Union Erasmus+ programme (H.K.A.R.).

\section{REFERENCES}

(1) Hodgson, D. M.; Charlton, A. Tetrahedron 2014, 70, 2207-2236.

(2) Enders, D.; Wortmann, L.; Peters, R. Acc. Chem. Res. 2000, 33, 157-69.

(3) Enders, D.; Demir, A. S.; Rendenbach, B. E. M. Chem. Ber. 1987, $120,1731-1735$.

(4) Evans, D. A.; Tedrow, J. S.; Shaw, J. T.; Downey, C. W. J. Am. Chem. Soc. 2002, 124, 392-393.

(5) Myers, A. G.; Yang, B. H.; Chen, H.; McKinstry, L.; Kopecky, D. J.; Gleason, J. L. J. Am. Chem. Soc. 1997, 119, 6496-6511.

(6) Job, A.; Janeck, C. F.; Bettray, W.; Peters, R.; Enders, D. Tetrahedron 2002, 58, 2253-2329.

(7) Vesely, J.; Rios, R. ChemCatChem 2012, 4, 942-953.

(8) Nicewicz, D. A.; MacMillan, D. W. C. Science 2008, 322, 77-80.

(9) For a recent report of fully catalytic asymmetric C-C bond formation at the $\alpha$-position of aldehydes by addition to styrenes and 2,2-dialkyl-substituted 1-olefins, see: Capacci, A. G.; Malinowski, J. T.; McAlpine, N. J.; Kuhne, J.; MacMillan, D. W. C. Nat. Chem. 2017, DOI: $10.1038 /$ nchem.2797.

(10) For an organocatalytic approach using 1,3-benzodithiolylium tetrafluoroborate as the electrophile that can indirectly achieve the equivalent of asymmetric $\alpha$-alkylation, see: Gualandi, A.; Emer, E.; Capdevila, M. G.; Cozzi, P. G. Angew. Chem., Int. Ed. 2011, 50, 78427846.

(11) (a) Hodgson, D. M.; Bray, C. D.; Kindon, N. D. J. Am. Chem. Soc. 2004, 126, 6870-6871. (b) Hodgson, D. M.; Kaka, N. S. Angew. Chem., Int. Ed. 2008, 47, 9958-9960. (c) Hodgson, D. M.; Bray, C. D.; Kindon, N. D.; Reynolds, N. J.; Coote, S. J.; Um, J. M.; Houk, K. N. J. Org. Chem. 2009, 74, 1019-1028. (d) Um, J. M.; Kaka, N. S.; Hodgson, D. M.; Houk, K. N. Chem. - Eur. J. 2010, 16, 6310-6316.

(12) Hodgson, D. M.; Charlton, A.; Paton, R. S.; Thompson, A. L. J. Org. Chem. 2013, 78, 1508-1518.

(13) Liu, F.; Houk, K. N. Acc. Chem. Res. 2017, 50, 539-543.

(14) Quantum-mechanical TS modeling: (a) Houk, K. N.; Cheong, P. H.-Y. Nature 2008, 455, 309-313. (b) Gammack-Yamagata, A. D.; Datta, S.; Jackson, K. E.; Stegbauer, L.; Paton, R. S.; Dixon, D. J. Angew. Chem. 2015, 127, 4981-4985. (c) Straker, R.; Peng, Q.; Mekareeya, A.; Paton, R. S.; Anderson, E. A. Nat. Commun. 2016, 7, 10109. Quantitative structure-selectivity relationships: (d) Kozlowski, M. C.; Waters, S. P.; Skudlarek, J. W.; Evans, C. A. Org. Lett. 2002, 4, 4391-4393. (e) Sigman, M. S.; Harper, K. C.; Bess, E. N.; Milo, A. Acc. Chem. Res. 2016, 49, 1292-1301.

(15) For an example of computationally-aided design for stereoselective enamine catalysis, see: Petruzziello, D.; Stenta, M.; Mazzanti, A.; Cozzi, P. G. Chem. - Eur. J. 2013, 19, 7696-7700.

(16) (a) Bahmanyar, S.; Houk, K. N. J. Am. Chem. Soc. 2001, 123, 11273-11283. (b) ibid. 12911-12912. (c) Hoang, L.; Bahmanyar, S.; Houk, K. N.; List, B. J. Am. Chem. Soc. 2003, 125, 16-17. (d) Bahmanyar, S.; Houk, K. N.; Martin, H. J.; List, B. J. Am. Chem. Soc. 2003, 125, 2475-2479. (e) Bahmanyar, S.; Houk, K. N. Org. Lett. 2003, 5, 1249-1251. (f) Clemente, F. R.; Houk, K. N. Angew. Chem., Int. Ed. 2004, 43, 5766-5768. (g) Allemann, C.; Gordillo, R; Clemente, F. R.; Cheong, P. H.-Y.; Houk, K. N. Acc. Chem. Res. 2004, 37, 558-569. (h) Allemann, C.; Um, J. M.; Houk, K. N. J. Mol. Catal. A: Chem. 2010, 324, 31-38.

(17) (a) Lam, Y.-h.; Grayson, M. N.; Holland, M. C.; Simon, A.; Houk, K. N. Acc. Chem. Res. 2016, 49, 750-762. (b) Simoń, L.; Goodman, J. M. Org. Biomol. Chem. 2011, 9, 689-700.

(18) qRRHO corrections were originally proposed in: (a) Ribeiro, R. F.; Marenich, A. V.; Cramer, C. J.; Truhlar, D. G. J. Phys. Chem. B 
2011, 115, 14556-14562. (b) Grimme, S. Chem. - Eur. J. 2012, 18, 9955-9964. we implemented the latter type using GoodVibes: FunesArdoiz, I.; Paton, R. S. GoodVibes: GoodVibes v1.0.0 2016, 1.

(19) Huddleston, R. R.; Cauble, D. F.; Krische, M. J. J. Org. Chem. 2003, 68, 11-14.

(20) Jarevång, T.; Anke, H.; Anke, T.; Erkel, G.; Sterner, O. Acta Chem. Scand. 1998, 52, 1350-1352.

(21) Naylor, A.; Howarth, N.; Malpass, J. R. Tetrahedron 1993, 49, 451-468.

(22) Thompson, W. J.; Anderson, P. S.; Britcher, S. F.; Lyle, T. A.; Thies, J. E.; Magill, C. A.; Varga, S. L.; Schwering, J. E.; Lyle, P. A.; Christy, M. E.; Evans, B. E.; Colton, C. D.; Holloway, M. K.; Springer, J. P.; Hirshfield, J. M.; Ball, R. G.; Amato, J. S.; Larsen, R. D.; Wong, E. H. F.; Kemp, J. A.; Tricklebank, M. D.; Singh, L.; Oles, R.; Priestly, T.; Marshall, G. R.; Knight, A. R.; Middlemiss, D. N.; Woodruff, G. N.; Iversen, L. L. J. Med. Chem. 1990, 33, 789-808.

(23) See the Supporting Information for details.

(24) (a) Curphey, T. J.; Hung, J. C. Y. Chem. Commun. 1967, 510. (b) Curphey, T. J.; Hung, J. C. Y.; Chu, C. C. C. J. Org. Chem. 1975, 40, 607-614.

(25) Ishikawa, T.; Uedo, E.; Okada, S.; Saito, S. Synlett 1999, 1999, $450-452$.

(26) Hansson, C.; Wickberg, B. J. Org. Chem. 1973, 38, 3074-3076.

(27) (a) Davis, F. A.; Edupuganti, R. Org. Lett. 2010, 12, 848-851. (b) For a review, see: Davis, F. A. Phosphorus, Sulfur Silicon Relat. Elem. 2016, 191, 297-304.

(28) (a) Bailey, W. F.; Punzalan, E. R. J. Org. Chem. 1990, 55, 54045406. (b) Nazef, N.; Davies, R. D. M.; Greaney, M. F. Org. Lett. 2012, $14,3720-3723$.

(29) Hostaš, J.; Řezáč, J. J. Chem. Theory Comput. 2017, 13, 35753585.

(30) In previous studies we employed a quasi-harmonic correction of the type proposed by Truhlar in ref 18a. In this study we adopt the more complex form of correction proposed by Grimme (ref 18b) due to the smaller dependency of the correction on the choice of frequency cutoff. This leads to very small numerical differences in Gibbs energies between B3LYP results from ref 12 and this work.

(31) Frisch, M. J.; Trucks, G. W.; Schlegel, H. B.; Scuseria, G. E.; Robb, M. A.; Cheeseman, J. R.; Scalmani, G.; Barone, V.; Petersson, G. A.; Nakatsuji, H.; Li, X.; Caricato, M.; Marenich, A. V.; Bloino, J.; Janesko, B. G.; Gomperts, R.; Mennucci, B.; Hratchian, H. P.; Ortiz, J. V.; Izmaylov, A. F.; Sonnenberg, J. L.; Williams-Young, D.; Ding, F.; Lipparini, F.; Egidi, F.; Goings, J.; Peng, B.; Petrone, A.; Henderson, T.; Ranasinghe, D.; Zakrzewski, V. G.; Gao, J.; Rega, N.; Zheng, G.; Liang, W.; Hada, M.; Ehara, M.; Toyota, K.; Fukuda, R.; Hasegawa, J.; Ishida, M.; Nakajima, T.; Honda, Y.; Kitao, O.; Nakai, H.; Vreven, T.; Throssell, K.; Montgomery, J. A., Jr.; Peralta, J. E.; Ogliaro, F.; Bearpark, M. J.; Heyd, J. J.; Brothers, E. N.; Kudin, K. N.; Staroverov, V. N.; Keith, T. A.; Kobayashi, R.; Normand, J.; Raghavachari, K.; Rendell, A. P.; Burant, J. C.; Iyengar, S. S.; Tomasi, J.; Cossi, M.; Millam, J. M.; Klene, M.; Adamo, C.; Cammi, R.; Ochterski, J. W.; Martin, R. L.; Morokuma, K.; Farkas, O.; Foresman, J. B.; Fox, D. J. Gaussian 09, Revision D.01; Gaussian, Inc.: Wallingford CT, 2016.

(32) (a) Becke, A. D. J. Chem. Phys. 1993, 98, 5648-5652. (b) Lee, C.; Yang, W.; Parr, R. G. Phys. Rev. B: Condens. Matter Mater. Phys. 1988, 37, 785-789. (c) Vosko, S. H.; Wilk, L.; Nusair, M. Can. J. Phys. 1980, 58, 1200-1211. (d) Stephens, P. J.; Devlin, F. J.; Chabalowski, C. F.; Frisch, M. J. J. Phys. Chem. 1994, 98, 11623-11627. (e) Chai, J. D.; Head-Gordon, M. Phys. Chem. Chem. Phys. 2008, 10, 6615-6620. (f) Zhao, Y.; Truhlar, D. G. Theor. Chem. Acc. 2008, 120, 215-241.

(33) (a) Grimme, S.; Antony, J.; Ehrlich, S.; Krieg, H. J. Chem. Phys. 2010, 132, 154104. (b) Grimme, S.; Ehrlich, S.; Goerigk, L. J. Comput. Chem. 2011, 32, 1456-1465. (c) Johnson, E. R.; Becke, A. D. J. Chem. Phys. 2006, 124, 174104.

(34) Hay, P. J.; Wadt, W. R. J. Chem. Phys. 1985, 82, 299-310.

(35) (a) Barone, V.; Cossi, M. J. Phys. Chem. A 1998, 102, 1995-

2001. (b) Cossi, M.; Rega, N.; Scalmani, G.; Barone, V. J. Comput. Chem. 2003, 24, 669-681.
(36) qRRHO and RRHO Gibbs energies are compared in the Supporting Information.

(37) Peng, Q.; Duarte, F.; Paton, R. S. Chem. Soc. Rev. 2016, 45, 6093-6107.

(38) (a) Johnson, E. R.; Keinan, S.; Mori-Sánchez, P.; ContrerasGarcía, J.; Cohen, A. J.; Yang, W. J. Am. Chem. Soc. 2010, 132, 64986506. (b) Contreras-Garcia, J.; Johnson, E. R.; Keinan, S.; Chaudret, R.; Piquemal, J.-P.; Beratan, D. N.; Yang, W. J. Chem. Theory Comput. 2011, 7, 625-632.

(39) The PyMOL Molecular Graphics System, Version 1.8 Schrödinger, LLC. Bondi atomic van der Waals radii: Bondi, A. J. Phys. Chem. 1964, 68, 441-451. 